\title{
Development of Microencapsulation Delivery System for Long-Term Preservation of Probiotics as Biotherapeutics Agent
}

\author{
Himanshu K. Solanki, ${ }^{1,2}$ Dipak D. Pawar, ${ }^{1}$ Dushyant A. Shah, ${ }^{3}$ Vipul D. Prajapati, \\ Girish K. Jani, ${ }^{1}$ Akil M. Mulla, ${ }^{1}$ and Prachi M. Thakar ${ }^{1}$ \\ ${ }^{1}$ Department of Pharmaceutics, S.S.R. College of Pharmacy, Sayli-Silvassa Road, Sayli, Silvassa, Dora and Nagar Haveli 396230, India \\ ${ }^{2}$ Hemchandracharya North Gujarat University, Patan, Gujarat 384265, India \\ ${ }^{3}$ APMC College of Pharmaceutical Education and Research, Motipura, Himmatnagar, Sabarkantha 383001, India
}

Correspondence should be addressed to Himanshu K. Solanki; solanki_hims@yahoo.co.in

Received 17 April 2013; Accepted 21 June 2013

Academic Editor: Salvatore Sauro

Copyright (C) 2013 Himanshu K. Solanki et al. This is an open access article distributed under the Creative Commons Attribution License, which permits unrestricted use, distribution, and reproduction in any medium, provided the original work is properly cited.

\begin{abstract}
The administration of probiotic bacteria for health benefit has rapidly expanded in recent years, with a global market worth $\$ 32.6$ billion predicted by 2014. The oral administration of most of the probiotics results in the lack of ability to survive in a high proportion of the harsh conditions of acidity and bile concentration commonly encountered in the gastrointestinal tract of humans. Providing probiotic living cells with a physical barrier against adverse environmental conditions is therefore an approach currently receiving considerable interest. Probiotic encapsulation technology has the potential to protect microorganisms and to deliver them into the gut. However, there are still many challenges to overcome with respect to the microencapsulation process and the conditions prevailing in the gut. This review focuses mainly on the methodological approach of probiotic encapsulation including biomaterials selection and choice of appropriate technology in detailed manner.
\end{abstract}

\section{Introduction}

As described by the Food and Agriculture Association of the United Nations (FAO) and World Health Organization (WHO), probiotic are a group of live microorganisms that, when administered in adequate amounts, confer a health benefit on the host [1]. Probiotic is a term that means "for life" and defined as "live microorganisms that beneficially affect the host's health by improving its microbial balance" [2]. Lactobacillus and Bifidobacteria are the two most common types of microbes which are extensively used as probiotics $[2,3]$. The use of probiotic bacterial culture stimulates the growth of preferred microorganisms, crowds out potentially harmful bacteria, and reinforces the body's natural defense mechanisms [4]. Some bacterial strains that have been widely discussed in the literature are outlined in Table 1 along with their therapeutic uses.

Lifestyle and eating habits play an important role in the overall health of individuals. Recently the use of probiotics for health benefits has increased, and hence it has created a huge market worldwide [5]. In the development of effective and safe encapsulated product, it is essential to maintain the adequate number of viable cells during the shelf life of the product as well as during the gastrointestinal (GI) tract transit after consumption [6-10].

Normally, any probiotic product must contain at least $10^{6}-10^{7} \mathrm{cfu}$ of viable probiotic bacteria per $\mathrm{g}$ of the product at the time of its consumption to exert beneficial effects on human health [1]. To overcome difficulty during development, microencapsulation technique is utilized to increase the viabilitys; of probiotic also several studies are carried out to investigate their role in different conditions in probiotic exposed [11-18].

1.1. Purpose of Microencapsulation. The purpose of microencapsulation of probiotic is to protects certain compound or biological cells against surrounding environment which destruct the core. It protects the bacteria from heat, oxygen, and moisture and also improves the flow properties during 


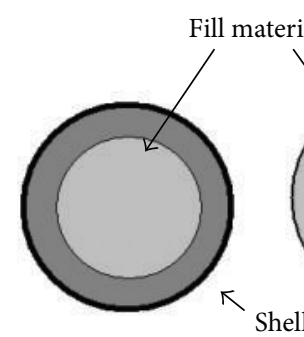

(a)

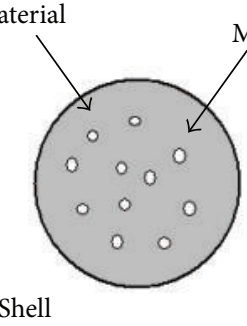

(b)

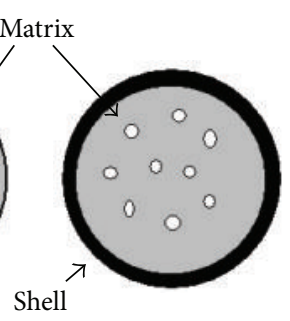

(c)
FIGURE 1: Schematic representation of encapsulation systems: (a) reservoir type, (b) matrix type, and (c) coated matrix type.

formulation development. It can be used for different drug delivery system and nowadays to apply for the encapsulation of probiotics in food product [19-21].

The core material is encapsulated in the food grade matrix type coating material. In the food industry, these materials form a barrier to protect the core material against the GI environment using different encapsulation systems as shown in Figure 1 [21].

Finally, microencapsulation gives structure and innovative system to the core material for the probiotic food product. Physicochemical properties of coating material affect the viability of encapsulated probiotic cells. Type and concentration of coating material, particle size, initial cell number, and bacterial strains are important during formulation [22].

1.2. Structure of Microcapsule. Microcapsules, formed by using natural materials like sugar, gums, protein, lipid, and synthetic or modified polymers, can be formulated as gel beads or in dried powder form. The formed smooth or irregular microcapsules lack their encapsulation efficiency because of the presence of pores [23]. The coating material is classified on the basis of the matrix material such as with a single wall material like sodium alginate, or a mixture material such as xanthan, gellan gum, alginate, and Chitosan. Coating material also affects the structure of microcapsule. Generally sodium alginate produces microcapsules with smooth surface [24], while slow gelling property of milk results in formation of irregular shaped capsule $[25,26]$. Different shapes of microspheres are shown in Figure 2.

\subsection{Advantages of Microencapsulated Probiotics}

(i) It protects and enhances survival of bacteria in foods.

(ii) It allows entrapped probiotic microorganisms to be incorporated into dairy products such as yogurt, cheese, and frozen milk product.

(iii) About $40 \%$ of Lactobacilli survive in frozen ice cream when entrapped in calcium alginate sphere than free cells [27].

(iv) The encapsulation of Bifidobacteria significantly improves survival, compared to free cells, throughout storage from $43 \%-44 \%$ to $50 \%-60 \%$ in frozen dairy product [28]. (v) Microencapsulated form of B. pseudolongum exhibits improvement of survival in a simulated gastric environment when compared to free viable microorganisms $[29,30]$.

\section{Factor Affecting Microencapsulation Effectiveness of Probiotics}

For evaluation of effectiveness of probiotic encapsulation process different parameters are considered such as viability maintenance after encountering detrimental environmental conditions, cell release/recovery ability, and hardening time (time needed for capsule formation). Different factors affecting the microencapsulation are discussed below $[23,31]$.

2.1. Effect of Various Biomaterials on Viability of Probiotics. A wide variety of biomaterials have been used by researchers in order to check their effects on the process of microencapsulation as well as on the viability of probiotic bacteria. Supported report is shown in Table 2.

\subsection{Capsule Characteristics with Respect to the Surrounding} Environment. Selection of capsular material with respect to the surrounding environment is very important. When the microcapsule is formed using alginate and different combination, leaks the calcium ions from alginate capsule structure leading to its decomposition. Hence it should be avoided from the highly acidic environment. If probiotic cells are to be targeted in the small intestine, then selection of capsule material(s) should be such that their decomposition occurs after subjecting them to the small intestine $\mathrm{pH}$ or pancreatic enzymes. If the beads are to be retained in the large intestine, it is preferable to be tolerant against the pancreas and small intestine conditions. However, this is not always easily achievable due to the restrictions in the chemical characteristics of encapsulation materials. Generally, all the capsules must be resistant to the acidic conditions of gastric juices [32]. Sometimes it is necessary to use special types of hydrophobic components of encapsulation to make the beads tolerant against moisture.

2.3. Coating of the Capsule. Efficient coating of capsule improves its physicochemical property. For example, shell coating on the alginate capsules makes them resistant to the chelating agents of calcium ions and also increases their mechanical strength.

2.4. Concentration of Capsule Making Solution and Bead Diameter. Concentration of capsule making solution and final bead diameter are factors which affect encapsulation efficiency. As bead diameter increases, it causes inappropriate mouth feel and flavor. Furthermore, increasing capsule diameter decreases digestibility by pancreatic enzyme.

2.5. Environmental Conditions. Physiology of the GI tract is important during the probiotic encapsulation process (Table 3) [205]. 


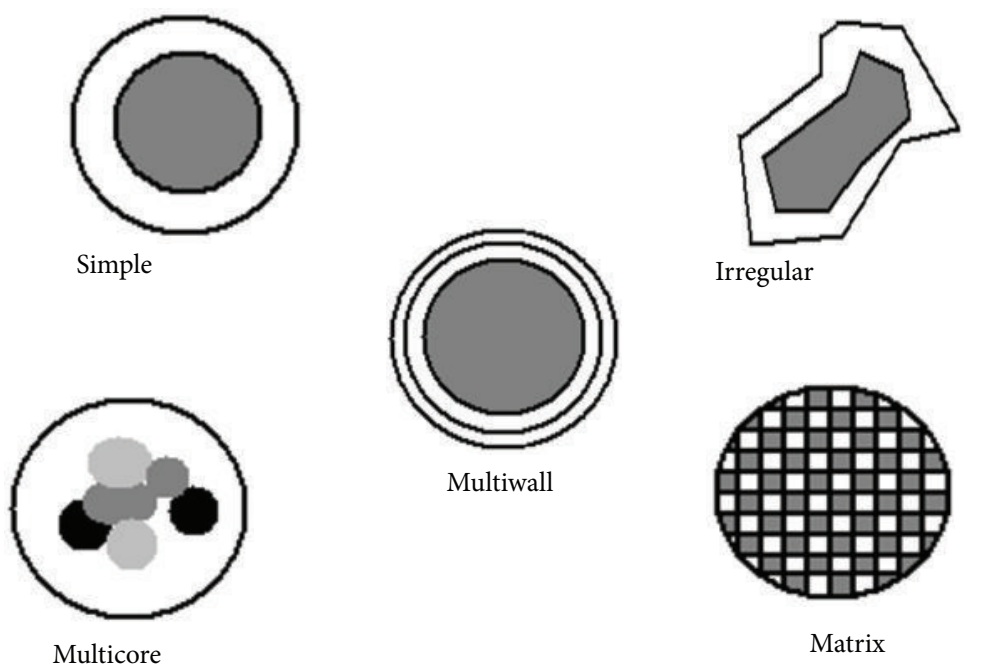

FIGURE 2: Various forms of microcapsule used in the food industry [19].

Environmental factors are also found to reduce encapsulation effectiveness.

2.6. Modification of Capsule Materials. Chemical modification of capsular material improves encapsulation effectiveness. Structural modification of the capsule materials is by direct structural changes and/or addition of special additives.

2.7. Initial Concentration of Microbial Cells. As concentration of microbial cells in the encapsulation solution increases, the number of entrapped cells in each bead (cell load) increases and, as a result, quantitative efficiency of encapsulation increases. If cell load exceeds the limit, softening of capsule structure occurs.

2.8. Conditions of Processing Factors. Microencapsulation processes such as freeze drying, spray drying, micronization, and storage conditions are employed in order to avoid injuries to the beads and contained cells.

\section{Formulation Technology for Microencapsulation of Probiotics}

The presence of diverse condition in human digestive system makes designing of the probiotic release system difficult. Hence, highly tailored system like specific target location system is required [205].

Probiotic cell is commonly encapsulated by extrusion, emulsion, and spray drying. In these methods, probiotic bacteria are entrapped in the gel matrix using different gel forming mechanisms [206]. Whereas probiotic are living cells, the condition for implementation technology are designed to maintain cell viability, and solvents involved in the encapsulation technology must be nontoxic [207]. In Figure 3, it the different types of particles obtained (matrix or reservoir type) by each method can be seen Figure 3 .

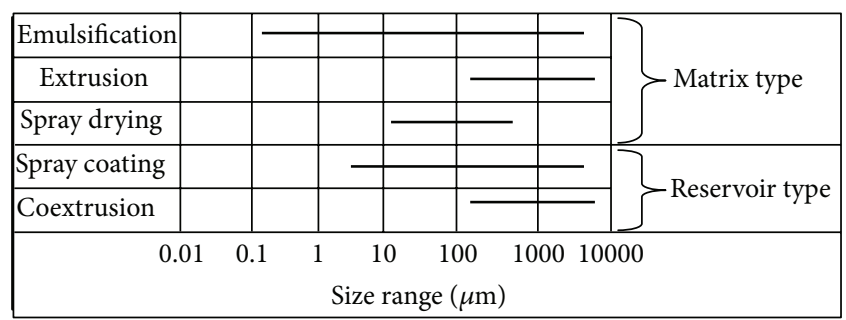

FIgURE 3: Probiotic encapsulation technologies: size range provided by each technique.

The ability of microorganisms to survive and multiply in the host strongly influences their probiotic benefits.

Microencapsulation techniques are divided into two parts:

(i) encapsulation process,

(ii) drying process.

3.1. Encapsulation Process. There are two basic techniques of microencapsulation that are used for encapsulation of probiotic bacteria. These encapsulated probiotics are then used for biomass production and also in various food products as functional food ingredients.

Depending on the method used, the two methods are extruded or droplet method and emulsion or two phase system method. From various studies it has been concluded that encapsulation by both of these methods has increased the viability of probiotic bacteria more than $80 \%$.

3.1.1. Extrusion Technique for Microencapsulation. It is the oldest common technique for probiotic formulation [208]. Extrusion method in the case of alginate capsule consists of the following stages: preparation of hydrocolloid solution and the addition of probiotic cell in hydrocolloid solution to form cell suspension. These cells suspension is passed through 
TABLE 1: Clinical studies of appropriate probiotic strains which have convincingly demonstrated their therapeutic effect.

\begin{tabular}{|c|c|c|}
\hline Most appropriate probiotic strain(s) & Therapeutic application & References \\
\hline $\begin{array}{l}\text { Lactobacillus plantarum 299v, Bacillus coagulans ATCC no. 31284, and Lactobacillus } \\
\text { acidophilus L1 }\end{array}$ & $\begin{array}{l}\text { Hypercholesterolemia and } \\
\text { cardiovascular disease }\end{array}$ & [33-36] \\
\hline Lactobacillus rhamnosus GG & Prevention of atopy & {$[37,38]$} \\
\hline Lactobacillus rhamnosus GG, Bifidobacterium lactis, and Lactobacillus paracasei & Eczema & [39-44] \\
\hline Lactobacillus rhamnosus GG, Bifidobacterium lactis, and Lactobacillus paracasei & Food allergies & [40-49] \\
\hline $\begin{array}{l}\text { Lactobacillus rhamnosus, Bifidobacterium lactis, Lactobacillus johnsonii, Lactobacillus } \\
\text { rhamnosus, and; Lactobacillus acidophilus }\end{array}$ & Lowered immunity & {$[50-60]$} \\
\hline $\begin{array}{l}\text { Lactobacillus rhamnosus GG, Saccharomyces cerevisiae, Lactobacillus acidophilus, and } \\
\text { Lactobacillus plantarum 299v }\end{array}$ & $\begin{array}{l}\text { Antibiotic use (during and } \\
\text { after) }\end{array}$ & {$[61-72]$} \\
\hline Lactobacillus rhamnosus GG & $\begin{array}{l}\text { Nonsteroidal } \\
\text { anti-inflammatory Drug }\end{array}$ & [73] \\
\hline Lactobacillus rhamnosus GG, Saccharomyces cerevisiae & $\begin{array}{l}\text { Intestinal } \\
\text { hyperpermeability }\end{array}$ & {$[41,42,74,75]$} \\
\hline $\begin{array}{l}\text { Lactobacillus rhamnosus GG, Lactobacillus reuteri MM53, Lactobacillus paracasei } \\
\text { CRL431, Lactobacillus acidophilus CRL730, Lactobacillus johnsonii La1, Bifidobacterium } \\
\text { lactis Bb12, Lactobacillus plantarum 299v, and Lactobacillus paracasei }\end{array}$ & Gastroenteritis & $\begin{array}{l}{[40,41,76-} \\
85]\end{array}$ \\
\hline $\begin{array}{l}\text { Lactobacillus johnsonii } \mathrm{Lal}^{\alpha}, \text { Lactobacillus plantarum } 299 \mathrm{v} \text {, and Lactobacillus rhamnosus } \\
\text { GG }\end{array}$ & Giardia infection & {$[77,86,87]$} \\
\hline $\begin{array}{l}\text { Lactobacillus rhamnosus GG, Lactobacillus johnsonii Lal, Lactobacillus plantarum 299v, } \\
\text { Lactobacillus paracasei, and propionibacterium freudenreichii HA-101 and HA-102 }\end{array}$ & Intestinal dysbiosis & $\begin{array}{l}{[64,65,88-} \\
\quad 93]\end{array}$ \\
\hline Lactobacillus acidophilus, Lactobacillus johnsonii Lal & Lactose intolerance & [94-98] \\
\hline Lactobacillus johnsonii La1, Lactobacillus acidophilus, and Lactobacillus rhamnosus GG & $\begin{array}{l}\text { Peptic ulcer disease } \\
\text { Nonerosive gastritis }\end{array}$ & {$[50,99-102]$} \\
\hline Lactobacillus plantarum 299v, VSL no. $3^{\beta}$ & Irritable bowel syndrome & [103-105] \\
\hline Lactobacillus acidophilus NCFB 1748, VSL no. $3^{\alpha}$ & $\begin{array}{l}\text { Radiation-induced } \\
\text { diarrhoea }\end{array}$ & {$[106,107]$} \\
\hline $\begin{array}{l}\text { Lactobacillus rhamnosus GG, Bifidobacterium lactis Bb12, Lactobacillus acidophilus, } \\
\text { Saccharomyces cerevisiae, and Lactobacillus plantarum 299v }\end{array}$ & Traveller's diarrhoea & $\begin{array}{l}{[77,84,108-} \\
110]\end{array}$ \\
\hline Lactobacillus rhamnosus GG, Saccharomyces cerevisiae & Crohn's disease & [111-114] \\
\hline Escherichia coli Nissle 1917, VSL no. $3^{\beta}$, Lactobacillus plantarum 299 & Ulcerative colitis & {$[115-119]$} \\
\hline $\begin{array}{l}\text { Lactobacillus rhamnosus GG, Lactobacillus acidophilus, Lactobacillus paracasei, } \\
\text { Lactobacillus acidophilus, and Lactobacillus delbrueckii ssp. bulgaricus strain LB-51 }\end{array}$ & Prevention of colon cancer & {$[120-124]$} \\
\hline $\begin{array}{l}\text { Lactobacillus rhamnosus GR-1, Lactobacillus fermentum B-54, Lactobacillus fermentum } \\
\text { RC-14, and Lactobacillus acidophilus }\end{array}$ & Urinary tract infection & {$[125-132]$} \\
\hline $\begin{array}{l}\text { Lactobacillus acidophilus, Lactobacillus rhamnosus GG, Lactobacillus rhamnosus GR-1, } \\
\text { and Lactobacillus fermentum RC-14 }\end{array}$ & $\begin{array}{l}\text { Vaginal candidiasis } \\
\text { (thrush) }\end{array}$ & {$[133-138]$} \\
\hline
\end{tabular}

the syringe needle to form droplets which are directly dripped into the hardening solution containimg cations like calcium. When the droplets come in contact with hardening solution, alginate polymers surround the core to form a threedimensional lattice structure by cross-linking calcium ions as shown in Figure 4 [22, 29, 146, 209, 210].

Thereby entrapping the core material separated from liquid bath and is dried using a suitable technology. Formation of gel by alginate solution $(0.6 \%)$ would be possible if calcium ion $(0.3 \mathrm{M})$ is present [193]. Usually, alginate is used in the range of $1-2 \%$ and $0.005-1.5 \mathrm{M}$ calcium chloride concentration. Generally, the diameter of forming beads in this method $(2-5 \mathrm{~mm})$ is larger than those formed in the emulsion method. Bead diameter is affected by concentration and viscosity of alginate solution and distance between the syringe and hardening solution, and diameter of extruder orifice affects the size of bead [156]. Bead diameter decreases along with increasing concentration and viscosity of the encapsulation solution. Using low glucuronic alginate, formation of beads with smaller diameter is possible [211]. For production of alginate capsule with Chitosan coat, alginate solution is dripped into the hardening batch containing calcium chloride and Chitosan $[201,212]$. Soaking of alginate beads in the Chitosan solution (0.1\%, pH 6.5) for $20 \mathrm{~min}$ forms beads with good properties [12].

Review work on this technique for probiotic microencapsulation is listed in Tables 4 and 5.

3.1.2. Emulsion Technique for Microencapsulation. It is successfully applied for the microencapsulation of lactic acid bacteria $[170,213]$. In this method, small volume of cell/polymer slurry (dispersed phase) is added to the large volume of vegetable oil (as a continuous phase) such as soy 
TABLE 2: Supported report provides evidence that encapsulation of probiotics results in increased viability.

\begin{tabular}{|c|c|c|}
\hline Sr. no. & Supported report provides evidence that encapsulation of probiotics results in increased viability & References \\
\hline 1 & $\begin{array}{l}\text { It has been investigated that when yoghurt isolates of L. acidophilus and Bifidobacterium are } \\
\text { encapsulated in } 2 \% \text { alginate solution, the viability was increased } 15.9 \% \text { and } 16.6 \% \text {, respectively, under } \\
\text { acidic and bile salt condition }\end{array}$ & [139] \\
\hline 2 & $\begin{array}{l}\text { The use of calcium-induced alginate starch coating has also improved the survivability of encapsulated } \\
\text { cells of Lactobacillus acidophilus and Bifidobacterium lactis (probiotic bacteria) up to } 2 \text { and } 1 \text { log cell } \\
\text { numbers, respectively, in yoghurt }\end{array}$ & {$[140]$} \\
\hline 3 & $\begin{array}{l}\text { Whey protein-based microcapsules can improve the cell survival of probiotic bacteria under extreme } \\
\text { conditions }\end{array}$ & {$[141]$} \\
\hline 4 & $\begin{array}{l}\text { A combination of gellan-alginate was used to encapsulate Bifidobacterium bifidum. The result showed } \\
\text { that } 2 \% \text { sodium alginate and } 1 \% \text { gellan gum used as encapsulating materials have provided the highest } \\
\text { thermotolerance in terms of B. bifidum count. The results of heat treatments also demonstrated that the } \\
\text { addition of gellan gum in the walls of probiotic microcapsules provided improved protection for } B \text {. } \\
\text { bifidum. The cell counts of B. bifidum remained at } 10^{5}-10^{6} \mathrm{CFU} / \mathrm{g} \text { for the microcapsules stored for } 2 \\
\text { months }\end{array}$ & {$[142]$} \\
\hline 5 & $\begin{array}{l}\text { Encapsulated cells also showed approximately } 10^{4} \text { times increase in viability during exposure to acidic } \\
\text { and bile salt conditions }\end{array}$ & {$[143]$} \\
\hline 6 & $\begin{array}{l}\text { It was found that cells microencapsulated in alginate, carrageenan, and xanthan gum survived better } \\
\text { than free cells following } 2 \mathrm{~h} \text { incubation in acidic condition }(\mathrm{pH} 2)\end{array}$ & {$[144]$} \\
\hline 7 & $\begin{array}{l}\text { It was found that cells encapsulated by extrusion using alginate and alginate with starch offered greater } \\
\text { protection to cells in simulated gastric juice }\end{array}$ & {$[24]$} \\
\hline 8 & $\begin{array}{l}\text { Chitosan coating of microbeads resulted in a significant increase in survival time of } L \text {. rhamnosus from } \\
40 \text { to } 120 \text { min in acid condition, and the reduction in cell numbers was confined to } 0.94 \text { log over this } \\
\text { time. Alginate macrobeads are more effective than microbeads in protecting } L \text {. acidophilus against high } \\
\text { acid and bile }\end{array}$ & [145] \\
\hline
\end{tabular}

TABLE 3: Relative $\mathrm{pH}$ and transit time at various locations within GIT.

\begin{tabular}{|c|c|c|}
\hline Region & $\mathrm{pH}$ & Transit time \\
\hline Oesophagus & $\sim 7.0$ & $10-14$ seconds \\
\hline Stomach & $1-2.5$ (up to $5 \mathrm{fed})$ & Half emptying: $\sim 80.5$ mins \\
\hline Proximal small intestine & $6.15-7.35$ & \multirow{2}{*}{$3.2 \pm 1.6 \mathrm{hrs}$ (combined) } \\
\hline Distal small intestine & $6.80-7.88$ & \\
\hline Ascending colon & $5.26-6.72$ & \multirow{2}{*}{ Highly variable, dependent on bowel evacuation } \\
\hline Descending colon & $5.20-7.02$ & \\
\hline
\end{tabular}

oil, sunflower, corn, and light paraffin oil [174]. After the formation of emulsion, cross-linking is required to form gels. Gelification is done by different mechanisms like ionic, enzymatic, and interfacial polymerization as discussed next. Reported works on this technique are listed in Table 6.

It can be easily scaled up, and the diameter of producing beads is considerably smaller $(25 \mu \mathrm{m}-2 \mathrm{~mm})$. It is costly due to need of vegetable oil, surfactant, and emulsifier (Tween 80 $(0.2 \%))$ for encapsulation in an emulsion $[27,175]$.

3.1.3. Emulsification Ionic Gelification. Emulsification is a chemical technique to encapsulate probiotic using alginate, carrageenan and pectin as an encapsulating material (Figure 5).

Once W/O emulsion is formed, water soluble polymer becomes insoluble after addition of ions of calcium chloride, by means of cross-linking forming gel particles in the oil phase. The smallest particle of the aqueous phase in $\mathrm{W} / \mathrm{O}$ phase emulsion will lead to the formation of beads with smaller diameters. Agitation rate and type of emulsifier also affects the diameter of the beads $[29,214]$. Microbeads produced by this technique are recovered by membrane filtration technology [29].

3.1.4. Emulsification and Enzymatic Gelification. In some countries, use of coating materials such as $\kappa$-carrageenan, gellan gum, or xanthan is not allowed in dairy product [141]. So milk protein is used to encapsulate probiotics by means of an enzyme-induced gelation [215, 216]. Milk proteins have excellent gelation properties and are a natural vehicle for probiotics [217]. This method gives water insoluble and spherical particles [215]. This method is an example of encapsulation by means of rennet gelation as shown in Figure 6, which is based on the principle of using dairy proteins which have been put in contact with rennet at low temperature. 
TABLE 4: Advantage and disadvantages of extrusion technique.

\begin{tabular}{ll}
\hline Advantages & Disadvantages \\
\hline (i) Simple and cheap method that uses a gentle operation & (i) Difficult to use for large scale production due to slow formation \\
(ii) No damage to the probiotic cell & of microbeads \\
(iii) Gives high probiotic viability [29] & (ii) Very poor payload of typically 8\% \\
(iv) Does not involve deleterious solvent & (iii) Susceptibility of carbohydrate towards damage and structural \\
(v) Done under aerobic and anaerobic conditions & defect, a larger size distribution \\
\hline
\end{tabular}

TABLE 5: Different probiotic strain, biomaterial, and size of microcapsule encapsulated by extrusion technique.

\begin{tabular}{|c|c|c|c|}
\hline Probiotic strain & Material & $\begin{array}{l}\text { Size of } \\
\text { capsule }\end{array}$ & Reference \\
\hline Lactobacillus bulgaricus, Streptococcus thermophilus & $1.875 \%$ alginate & $2.5 \mathrm{~mm}$ & {$[148]$} \\
\hline $\begin{array}{l}\text { Streptococcus lactis ssp. diacetylactis } \\
\text { Streptococcus cremoris }\end{array}$ & $1.875 \%$ alginate & $2.6 \mathrm{~mm}$ & [149] \\
\hline Streptococcus cremoris & $1 \%$ alginate & - & {$[150]$} \\
\hline Lactococcus lactis ssp. cremoris & $2 \%$ alginate $+0.4 \%$ chitosan & $2 \mathrm{~mm}$ & {$[12,147]$} \\
\hline Lactobacillus plantarum & $2 \%$ Alginate $+10 \%$ skim milk & $2 \mathrm{~mm}$ & {$[151]$} \\
\hline Lactococcus lactis ssp. lactis bv. diacetylactis & $1.5 \%$ alginate & - & {$[152]$} \\
\hline Lactococcus lactis ssp. cremoris & $2 \%$ alginate & - & {$[153]$} \\
\hline $\begin{array}{l}\text { Streptococcus thermophilus } \\
\text { Lactobacillus delbrueckii ssp. } \\
\text { bulgaricus }\end{array}$ & $2 \%$ alginate & - & {$[154]$} \\
\hline Lactococcus lactis ssp. lactis bv. diacetylactis & $1.8 \%$ alginate & & {$[155]$} \\
\hline Lactobacillus acidophilus & $0.6 \%$ alginate + starch & $5 \mathrm{~mm}$ & {$[156]$} \\
\hline Bifidobacterium lactis & $\begin{array}{l}0.75 \% \text { gellan gum }+1 \% \text { xanthan } \\
\text { gum }\end{array}$ & $3 \mathrm{~mm}$ & {$[32,157,158]$} \\
\hline Lactobacillus reuteri & $1 \%$ xanthan gum $+0.5 \%$ gellan gum & - & {$[24]$} \\
\hline Lactococcus lactis & $1 \%$ alginate, poly-L-lysine & $2 \mathrm{~mm}$ & {$[159]$} \\
\hline Lactobacillus reuteri & $\begin{array}{l}1.5 \% \text { alginate }+0.1 \% \text { poly-L-lysine } \\
\text { and } 0.1 \% \text { alginate }\end{array}$ & $619 \mu \mathrm{m}$ & {$[160]$} \\
\hline Lactobacillus spp. & $1.8 \%$ alginate & $330-450 \mu \mathrm{m}$ & {$[161]$} \\
\hline Lactococcus lactis ssp. cremoris & $2 \%$ alginate & $1.62 \mathrm{~mm}$ & {$[12]$} \\
\hline Lactococcus lactis ssp. cremoris & $2 \%$ alginate $+0.17 \%$ alginate & $1.89 \mathrm{~mm}$ & {$[12]$} \\
\hline Saccharomyces boulardii & $1.8 \%$ alginate $+0.4 \%$ chitosan & $356 \mu \mathrm{m}$ & {$[162]$} \\
\hline Lactobacillus reuteri & $2 \%$ alginate $+2 \%$ corn starch & - & {$[24]$} \\
\hline Lactococcus lactis ssp. cremoris & $2 \%$ alginate $+0.05 \%$ poly-L-lysine & $1.89 \mathrm{~mm}$ & {$[12]$} \\
\hline Bifidobacterium bifidum & $\begin{array}{l}2 \% \text { alginate, } 1 \% \text { gellan, } 0.86 \% \\
\text { peptides, } 0.2 \% \text { FOS }\end{array}$ & - & {$[163]$} \\
\hline $\begin{array}{l}\text { Lactobacillus acidophilus, Lactobacillus casei, Bifidobacterium } \\
\text { bifidum, and Bifidobacterium longum }\end{array}$ & $3 \%$ alginate, $1 \%$ peptides, $3 \%$ FOS & - & {$[164]$} \\
\hline Bifidobacterium longum & $2-4 \%$ alginate & $1.03-2.62 \mathrm{~mm}$ & {$[165]$} \\
\hline Lactobacillus reuteri, Escherichia coli & $3 \%$ alginate & - & {$[24,166,167]$} \\
\hline Lactobacillus reuteri & $\begin{array}{l}1.75 \% \kappa \text {-carrageenan }+0.75 \% \text { locust } \\
\text { bean gum }\end{array}$ & - & {$[24]$} \\
\hline Lactobacillus acidophilus, Bifidobacterium lactis & $1.8 \%$ alginate $+1 \%$ Hi-Maize starch & - & {$[140,168]$} \\
\hline Bifidobacterium bifidum & $3 \% \kappa$-carrageenan & - & [169] \\
\hline
\end{tabular}


TABLE 6: Different probiotic strain, biomaterial, and size of microcapsule encapsulated by emulsion technique.

\begin{tabular}{|c|c|c|c|}
\hline Probiotic strain & Material & $\begin{array}{c}\text { Size of } \\
\text { microcapsule }\end{array}$ & Reference \\
\hline Streptococcus thermophilus & $\begin{array}{l}3 \% \kappa \text {-carrageenan and locust bean gum } \\
\qquad(2: 1)\end{array}$ & $0.5-2 \mathrm{~mm}$ & {$[170]$} \\
\hline Bifidobacterium pseudolongum & $10 \%$ cellulose acetate phthalate & - & {$[171]$} \\
\hline Lactobacillus delbrueckii ssp. bulgaricus & $3 \%$ alginate & - & {$[172]$} \\
\hline Lactobacillus casei ssp. casei & $\begin{array}{l}3 \% \kappa \text {-carrageenan and locust bean gum } \\
\qquad(11: 1)\end{array}$ & $1-2 \mathrm{~mm}$ & [173] \\
\hline Lactococcus lactis ssp. cremoris & Chitosan $(4 \%)$ & $150 \mu \mathrm{m}$ & {$[174]$} \\
\hline Lactobacillus delbrueckii ssp. bulgaricus & $3.6 \%$ alginate & $30 \mu \mathrm{m}$ & {$[175]$} \\
\hline Lactobacillus delbrueckii ssp. bulgaricus & $3 \%$ alginate & $25-35 \mu \mathrm{m}$ & {$[27]$} \\
\hline Lactococcus lactis ssp. cremoris & $24 \%$ gelatin & $271-168 \mu \mathrm{m}$ & {$[176]$} \\
\hline Lactococcus lactis ssp. cremoris & $2 \%$ alginate & $50 \mu \mathrm{m}-1 \mathrm{~mm}$ & {$[177]$} \\
\hline $\begin{array}{l}\text { Bifidobacterium bifidum, Bifidobacterium } \\
\text { infantis }\end{array}$ & $3 \%$ alginate & - & {$[28]$} \\
\hline Lactobacillus casei NCDC-298 & $2-4 \%$ alginate & - & {$[178]$} \\
\hline Lactobacillus bulgaricus KFRI 673 & $\begin{array}{l}2 \% \text { alginate, } 5 \% \text { glycerol, } 0.26 \% \text { xanthan } \\
\text { gum }+0.8 \% \text { chitosan }\end{array}$ & $40-80 \mu \mathrm{m}$ & {$[179]$} \\
\hline Lactobacillus reuteri & $2 \%$ alginate $+2 \%$ corn starch & - & {$[24]$} \\
\hline $\begin{array}{l}\text { Lactobacillus acidophilus, Bifidobacterium } \\
\text { lactis }\end{array}$ & $2 \%$ alginate $+2 \%$ Hi-Maize starch & $0.5-1 \mathrm{~mm}$ & $\begin{array}{l}{[140,180,} \\
181]\end{array}$ \\
\hline Lactobacillus reuteri & $\begin{array}{l}1.75 \% \kappa \text {-carrageenan }+0.75 \% \text { locust bean } \\
\text { gum }\end{array}$ & - & {$[24]$} \\
\hline Bifidobacterium breve & Milk fat $+10 \%$ whey protein isolate & $3-80 \mu \mathrm{m}$ & {$[141]$} \\
\hline Lactobacillus reuteri & $1 \%$ xanthan $+0.5 \%$ gellan & & {$[24]$} \\
\hline Bifidobacterium adolescentis $15703 \mathrm{~T}$ & $13 \%$ gelatin, $1.25 \mathrm{mM}$ genipin $+1 \%$ alginate & $49-53 \mu \mathrm{m}$ & {$[182]$} \\
\hline
\end{tabular}

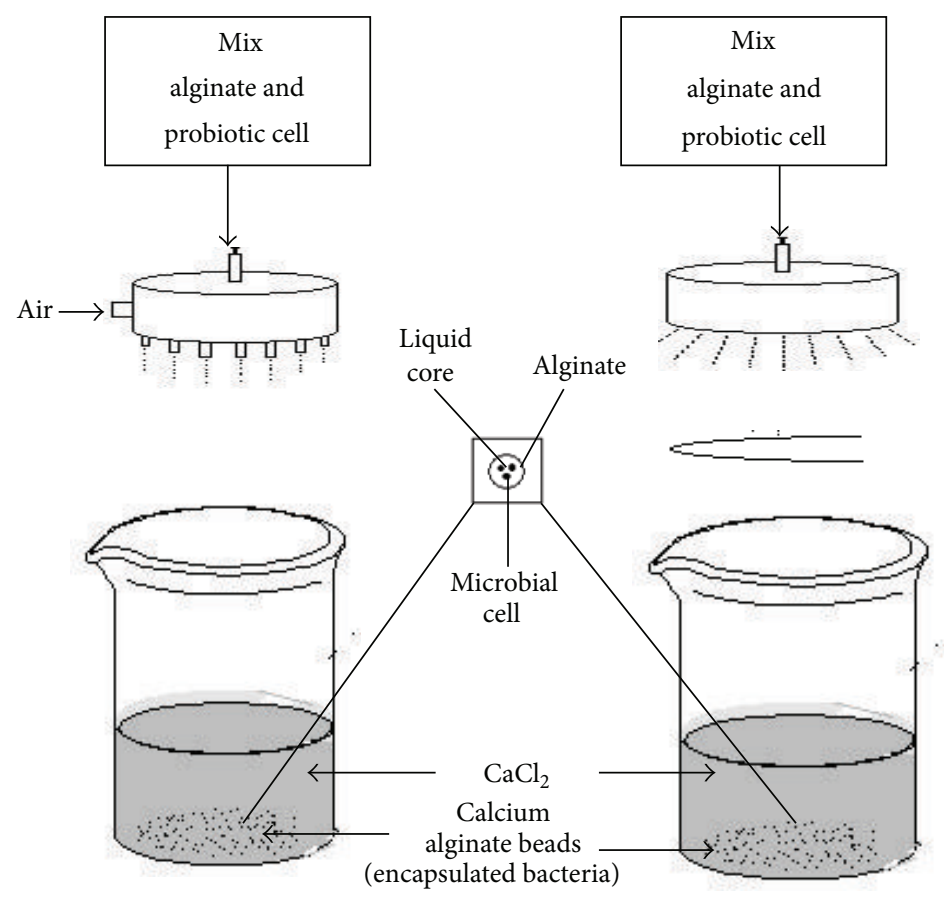

FIGURE 4: Extrusion technologies: simple needle droplet generator that usually is air driven (a) and pinning disk (b). The probiotic cells are added to the hydrocolloid solution and dripped through a syringe needle or a nozzle spray machine in the form of droplets which are allowed to free fall into a hardening solution such as calcium chloride. 

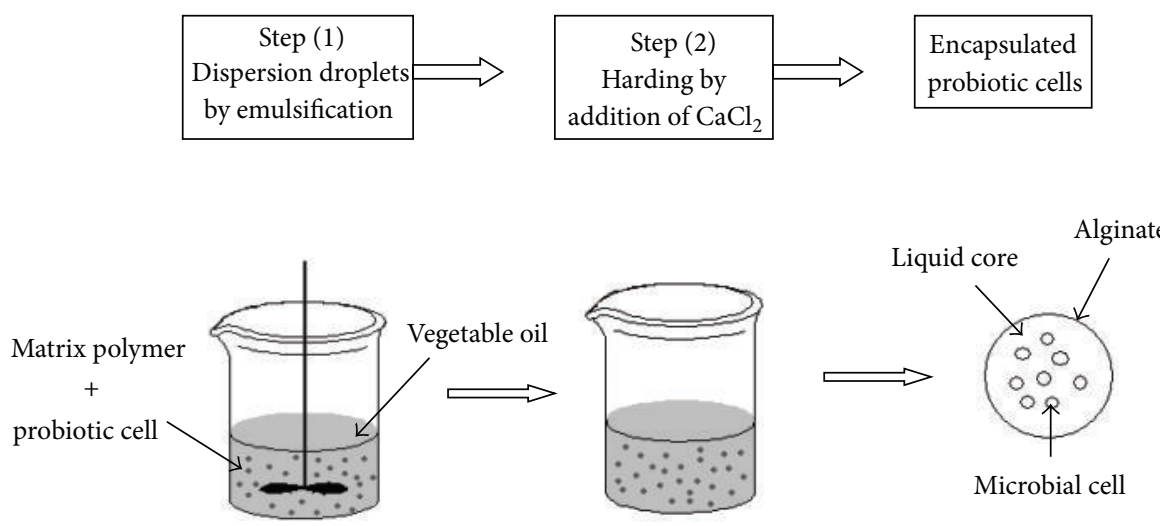

Microbial cell

FIGURE 5: Schematic presentation of emulsification procedure: a small volume of the cell polymer suspension (i.e., the discontinuous phase) is added to a large volume of vegetable oil (i.e., the continuous phase). The mixture is then homogenized to form a water-in-oil emulsion. Once the water-in-oil emulsion is formed, the water-soluble polymer must be insolubilized to form tiny gel particles within the oil phase.
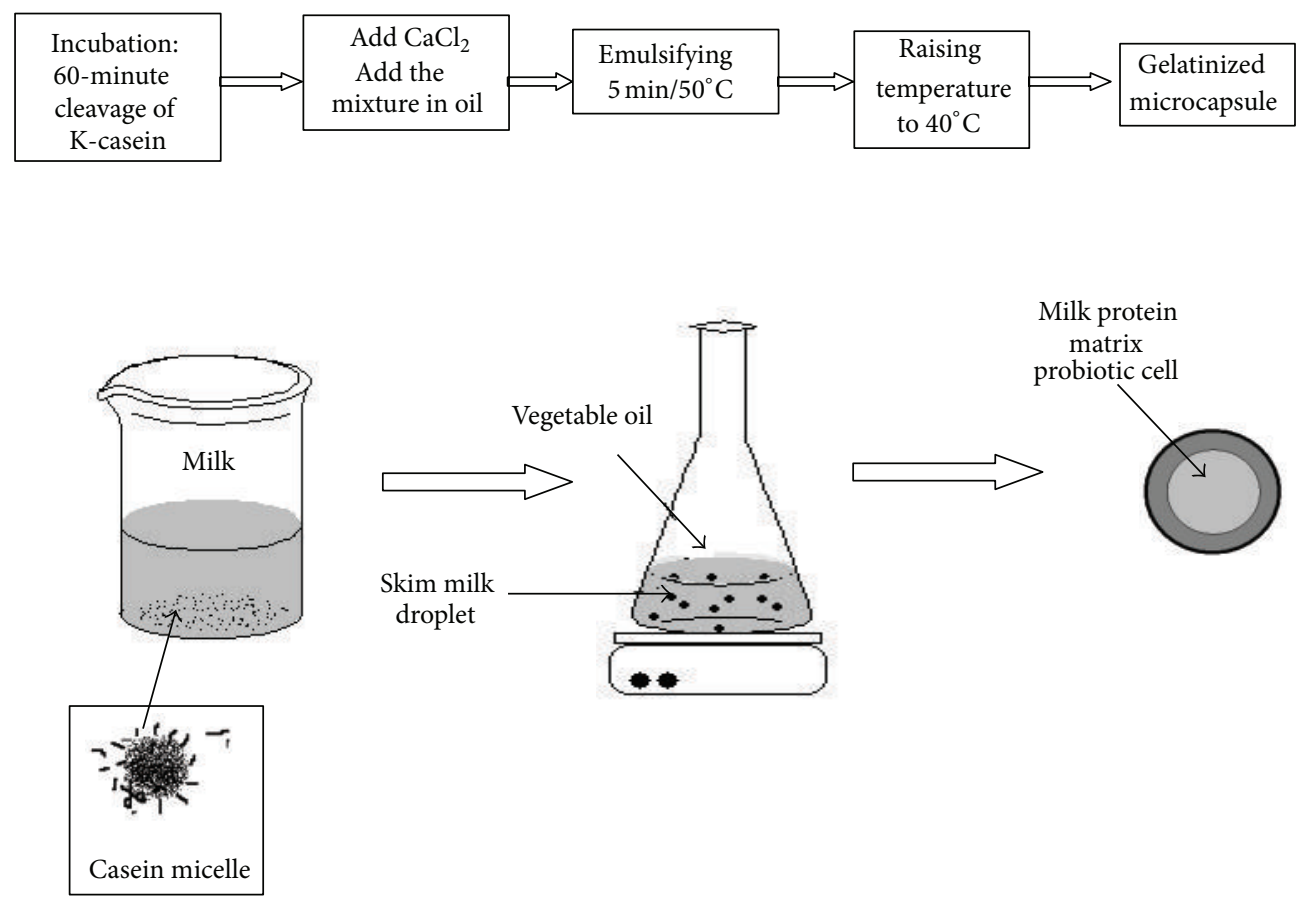

FIGURE 6: Schematic presentation of the microencapsulation of probiotic cells by means of rennet-gelation of milk proteins: The principle of the technique is based on using dairy proteins which have been put in contact with rennet at low temperature. This allows keeping a liquid system where $\kappa$-casein is cleaved by the enzyme. After that, dairy proteins have been emulsified in a cold oil to form water in oil emulsion. Thermal induction of enzymatic coagulation allows proteins flocculation and provides microparticles where probiotics are dispersed in coagulated dairy proteins.

This allows keeping a liquid system where $\kappa$-casein is cleaved by the enzyme. After that, dairy proteins are emulsified in a cold oil to form water in oil emulsion. Thermal induction of enzymatic coagulation allows protein flocculation and provides microparticles.

3.1.5. Emulsification and Interfacial Polymerization. This technique is a single step. It requires formation of an emulsion in which discontinuous phase contains an aqueous suspension of the cell and continuous phase contains organic solvent. To initiate the polymerization reaction, biocompatible agent which is soluble in the continuous phase is added. The drops of probiotic cell are coated to form thin and strong membrane [194]. Productivity of microorganisms is improved by interfacial polymerization in fermentation [218].

3.2. Drying Process for Microencapsulation. Drying improves stability of the encapsulated culture during prolonged storage. But the drying process causes some injuries to the microbeads, release of some cells, and reducing the viability 


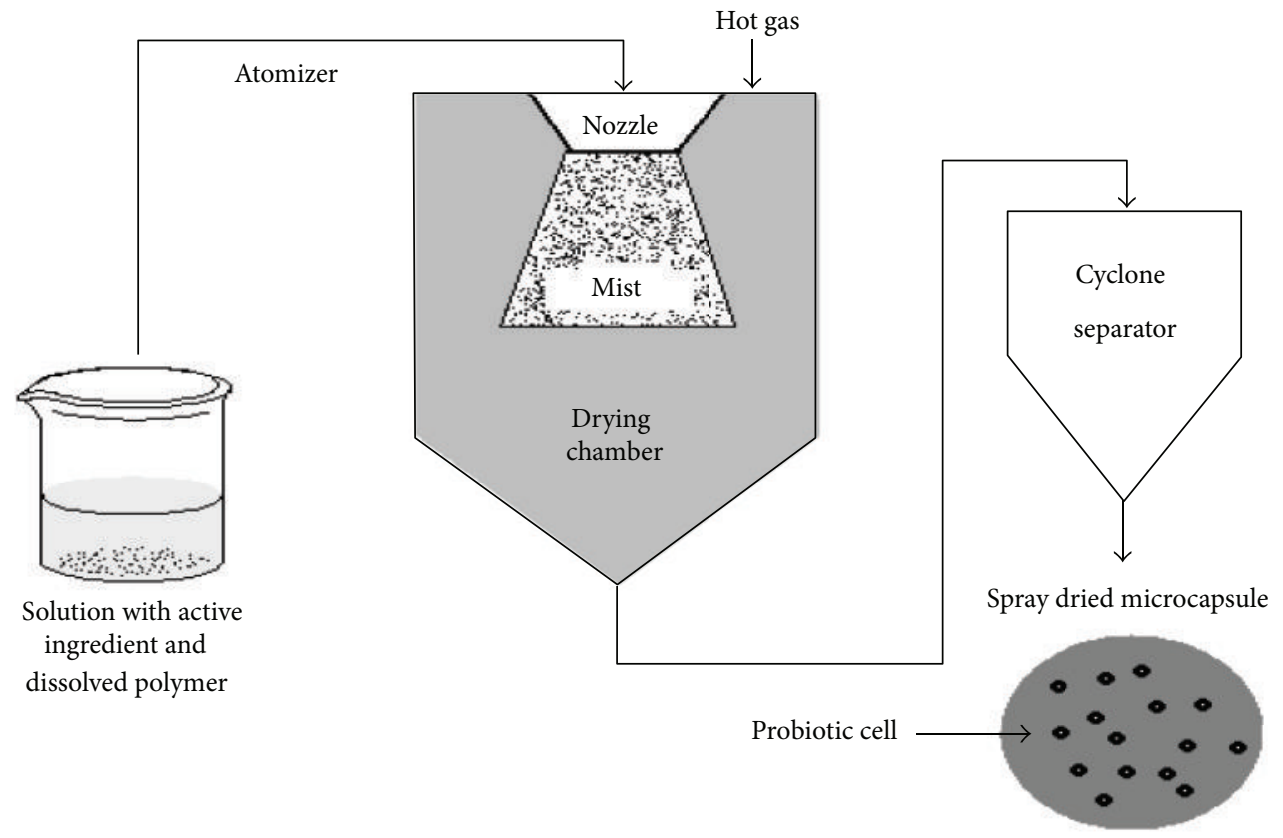

FIGURE 7: Schematic presentation of the spray-drying procedure: The solution is pressured and then atomized to form a "mist" into the drying chamber. The hot gas (air or nitrogen) is blown into the drying chamber too. This hot gas allows the evaporation of the solvent. The capsules are then transported to a cyclone separator for recovery.

of cells. Spray drying, freeze drying, and fluidized bed drying are common drying technology of probiotics used in industry and are summarized next [219].

3.2.1. Spray Drying. A solution containing probiotic living cells and the dissolved polymer matrix is prepared by using gum Arabic and starches because they tend to form a spherical microparticle during the drying process (Figure 7) $[22,209,210]$.

In drying process, probiotic cell loses viability due to physical injury to microencapsule and heat generation (Table 8) [23]. So the loss of probiotic cell can be reduced by using proper cryoprotectant during freeze drying, optimizing the inlet and outlet temperature for spray drying [206] (Table 7).

Table 7 Presents the coating materials and temperatures used in this technique for probiotic microencapsulation.

3.2.2. Freeze Drying. In this technique, the solvent is frozen and removed via sublimation [220]. Freezing causes damage to the cell membrane due to ice crystal formation and also imparts stress condition by high osmolarity. It has been traditionally used to stabilize probiotic bacteria, but the combination of freeze-drying and encapsulation is relatively new concept. Recently, Lactobacillus F19 and Bifidobacterium Bb12 cells were first encapsulated into enzymatically gelled sodium caseinate, and gel particles were freeze-dried to study the storage stability [17]. They reported better postdrying survival and storage viability for encapsulated cell compared to free cell. In other recent work, gelatinized starch and lecithin were incorporated into the alginate microcapsule containing probiotic organisms in encapsulated form, and beads were freeze-dried to evaluate the storage stability at different temperature. It was shown that encapsulated bacteria had much better stability at $23^{\circ} \mathrm{C}$ for 12 weeks, and lecithin helped in obtaining higher efficiency and more stability [221].

3.3. The Other Drying Method Used for Microencapsulation. The other drying techniques are listed below.

3.3.1. Fluidized Bed Drying. In this process, cell suspension is sprayed and dried on inert carriers using a Wurster-based fluidized bed system (Table 9) [222].

3.3.2. Vacuum Drying. Vacuum drying is suitable for heat sensitive probiotics because drying takes place at lower temperatures, and oxidation reaction can also be minimized, while disadvantage is batch operation and longer drying time which can be minimized by using a continuous vacuum dryer where cost is one-third of a freeze dryer, and the material can be dried at $1-4 \%$ moisture level at $40^{\circ} \mathrm{C}$ within 5-10 $\min$ [223].

\subsection{Another Technique for Encapsulation}

3.4.1. Spray Freeze Drying. In this technique, the probiotic cell solution is atomized into a cold vapor phase of a cryogenic liquid such as liquid nitrogen, which generates a dispersion of frozen droplets. These are dried in freeze dryer (Table 10) [200, 209, 210, 224]. 
TABLE 7: Different probiotic strain, biomaterial, inlet/outlet temperature, and size of microcapsule encapsulated by spray drying techniques.

\begin{tabular}{|c|c|c|c|c|}
\hline Probiotic strain & Material & $\begin{array}{l}\text { Inlet/outlet } \\
\text { temperature }\end{array}$ & $\begin{array}{l}\text { Size of capsule } \\
\mu \mathrm{m}\end{array}$ & Reference \\
\hline $\begin{array}{l}\text { Bifidobacterium infantis CCRC 14633, Bifidobacterium } \\
\text { infantis CCRC 14661, Bifidobacterium longum ATCC } \\
\text { 15708, Bifidobacterium longum CCRC 14634, } \\
\text { and Bifidobacterium longum B6 }\end{array}$ & $\begin{array}{l}10 \% \text { gelatin, gum arabic, } \\
\text { soluble starch, or skim milk }\end{array}$ & $100^{\circ} \mathrm{C} / 50^{\circ} \mathrm{C}$ & $10-20$ & [183-185] \\
\hline Lactobacillus paracasei NFBC 338 & $20 \%$ skim milk & $175^{\circ} \mathrm{C} / 68^{\circ} \mathrm{C}$ & - & {$[186]$} \\
\hline Lactobacillus rhamnosus GG & $\begin{array}{l}20 \% \text { skim milk + Raftilose } \\
\text { or Polydextrose }\end{array}$ & $-180^{\circ} \mathrm{C}$ & & {$[187]$} \\
\hline $\begin{array}{l}\text { Bifidobacterium breve R070 (BB R070), Bifidobacterium } \\
\text { longum R023 (BL R023), and Lactobacillus acidophilus } \\
\text { R335 (LA R335) }\end{array}$ & $10 \%$ whey protein isolate & $160^{\circ} \mathrm{C} / 80^{\circ} \mathrm{C}$ & $5-80$ & {$[188]$} \\
\hline Bifidobacterium PL1 & $10 \%$ waxy maize starch & $100^{\circ} \mathrm{C} / 45^{\circ} \mathrm{C}$ & 5 & [189] \\
\hline $\begin{array}{l}\text { Lactobacillus acidophilus BCRC 14079, Bifidobacterium } \\
\text { longum BCRC } 14605\end{array}$ & $\begin{array}{l}30 \% \text { maltodextrin }+20 \% \\
\text { gum arabic }\end{array}$ & $100^{\circ} \mathrm{C} / 50^{\circ} \mathrm{C}$ & 10 & {$[190]$} \\
\hline $\begin{array}{l}\text { Lactobacillus acidophilus La-05 } \\
\text { Bifidobacterium lactis } \mathrm{Bb}-12\end{array}$ & Cellulose acetate phthalate & $130^{\circ} \mathrm{C} / 75^{\circ} \mathrm{C}$ & 22 & {$[191]$} \\
\hline Lactobacillus paracasei NFBC 338 & Gum acacia (gum arabic) & $170^{\circ} \mathrm{C} / 95-105^{\circ} \mathrm{C}$ & $5-15$ & {$[192]$} \\
\hline
\end{tabular}

TABLE 8: Advantage and disadvantages of spray drying techniques.

\begin{tabular}{ll}
\hline Advantages & Disadvantages \\
\hline & $\begin{array}{l}\text { (i) However, spray drying may not be suitable particularly for } \\
\text { probiotic bacteria due to requirement of high temperature drying }\end{array}$ \\
The advantages of the spray drying process are ease of scaling & {$[19,193,194]$} \\
up, low operational cost, continuous operation, and adaptability & (ii) The loss of viability also depends upon the type of carrier used, for \\
to most common industrial equipment & $\begin{array}{l}\text { example, log reduction in soluble starch found to be higher compared } \\
\text { to other carriers such as alginate, gum Arabic, and skim milk }\end{array}$ \\
& {$[183,195]$}
\end{tabular}

3.4.2. Encapsulation by Coating and Agglomeration. In this method, solid form of core material is kept in motion in a specially designed vessel (Figure 8) [206, 210].

It is easy to scale up hence used in the encapsulation of probiotics for nutraceutical. The Canadian private company developed and patented a microencapsulation technique known as Probiocap [225]. The process is based on coating freeze-dried Lactobacillus with fatty acids. This technology allows strains to resist the harsh effect of temperature, gastric acidity, and compression. Danish-Korean Company patented a duel coating technology for Lactobacillus, which is marketed under the brand name Duaolac. The first layer of coating is made of soy peptide, and the second layer is made of cellulose and gum.

3.4.3. Coacervation Technique for Encapsulation. In coacervation process, colloidal particle is separated from a solution and deposited around core material. It is used in encapsulating flavor oil but is also used in fish oil, vitamin, enzyme, nutrients, and preservatives (Table 11). It is a threestep process comprising of phase separation, deposition, and solidification [26]. In the first step, coating material containing one or more polymer goes through a phase separation process and forms a coacervate. Suspended or emulsified form of core material remains, and as soon as wall material particles coalesce, it causes a decrease in surface area and total free interfacial energy of the system. In this process, coacervate nuclei adsorption to the surface of core material and form uniform layer around the core particles. Finally solidification of coating material is done by crosslinking using chemical, thermal, or enzymatic method. The formed microparticles are then collected by filtration or mild centrifugation followed by drying $[26,193]$.

Glutaraldehyde, cross-linking agent, is not applied in the food industry due to toxicity issues; thus cross-linking enzyme transglutaminase is used $[26,226]$.

3.4.4. Cocrystallization. It is mainly used for the fruit juices, essential oils, flavor, and brown sugar [193]. In this method, core material is dispersed in supersaturated sucrose solution maintained at high temperature. The heat is gradually released allowing the solution to crystallize with the core material. Finally the product is dried and sieved as per the particle size requirement (Table 12) [227].

3.4.5. Molecular Inclusion. This method involves entrapment of smaller molecule inside the hollow cavity of a larger molecule [193, 228]. Cyclodextrins are commonly used but restricted in the certain countries. In controlled release mechanism, core material is released when displaced by more favorable substrates. It is reported that $\beta$-cyclodextrin molecules containing core compound are highly heat stable, 
TABle 9: Advantage and disadvantages of fluidized bed drying.

\begin{tabular}{ll}
\hline Advantages & Disadvantages \\
\hline $\begin{array}{l}\text { The advantages of this process are total } \\
\text { control over the temperature, lower }\end{array}$ & Disadvantage being relatively longer duration (up to 2 hours) [195]. Before this \\
comparable cost & drying, probiotic culture is encapsulated first in supporting material such as \\
skimmed milk [196], potato starch [197], calcium alginate [198], or casein [199]
\end{tabular}

TABLE 10: Advantages and Disadvantages of spray freeze drying.

\begin{tabular}{ll}
\hline Advantages & Disadvantages \\
\hline & (i) Disadvantages are required high energy, long time, expensive than spray drying \\
The advantages are controlled size, large & {$[21]$} \\
specific surface area than spray dried capsule & (ii) Additional coating is given to capsule for protection against adverse \\
& environmental conditions [200]
\end{tabular}

can tolerate up to $200^{\circ} \mathrm{C}$, and are highly resistant to chemical degradation [146, 228].

Some of the major limitations of this molecular inclusion technology are low payload [146] and high cost of raw material [193].

3.4.6. Centrifugal Extrusion Technique. In this technique, core and coating materials are pumped through a separate tube to the surface of rotating cylinder. With the rotational motion of the cylinder, both materials are mixed and extruded as a fluid rod which is broken by the centrifugal force. The coating over the core material forms capsules caused by the difference in surface tension. Finally, formed capsules are placed on a moving bed of starch, which absorbs excess moisture and cushion the impact [26].

It is used in the food industry to encapsulate ingredients such as a flavor and seasoning [26], aspartame, vitamin, and methionine [19]. It produces smaller particles with a wide range of coating materials such as gelatin, alginate, carrageenan, starches, fatty acid, and waxes $[19,26]$.

The major advantage of this method is slower release properties of the capsule and higher throughput rate in comparison to the spray drying process [146].

\section{Biomaterials Used for Microencapsulation of Probiotics}

This section aims to provide a short overview of commonly used bilateral to encapsulate probiotic cells.

Definition. "Any natural material or not, which is in contact with a living structure and is intended to act with biological system." It includes natural and synthetic polymerswhich are directly in contact with living cell so they should be biocompatible and biodegradable [229]. Encapsulation of probiotics in biodegradable polymer matrix has a number of advantages. Cryo- and osmoprotection agent can be incorporated into the matrix which enhances the survival of cell during storage and processing. Finally, microcapsules are dried; surface coating is altering the aesthetic and sensory properties of product and provides a high level of protection to the cells. It helps in the delayed release of cell by maintaining the dissolution properties of the coating layer. Microcapsule produced by using polymer is easy on a lab scale. But the scaling process is very difficult and processing cost is very high.

4.1. Use of Alginate System for Encapsulation of Probiotics. Alginate is a naturally derived polysaccharide extracted from various species of algae and composed of two monosaccharide units: $\alpha$-L-guluronic acid (G) and $\beta$-D-mannuronic acid (M) linked from $\beta$ (1-4) glycosidic bond [230, 231]. M/G ratios determine the technological functionality of alginate. The gel strength depends upon high proportion block $\mathrm{G}$. High temperature $\left(60^{\circ} \mathrm{C}\right.$ to $\left.80^{\circ} \mathrm{C}\right)$ is needed to dissolve alginate in water. Alginate gels are insoluble in acidic media $[6,165,232,233]$. Usually alginate is used in concentration range of $0.5-4 \%$ (Table 13 ) [27].

4.2. Use of Chitosan for Encapsulation of Probiotics. Chitosan is a linear polysaccharide with negative charge arising from its amine groups obtained by deacetylation of chitin. It can be isolated from crustacean shells, insect cuticles, and the membranes of fungi. It is a copolymer of two monomer residues anhydro- $\mathrm{N}$-acetyl-D-glucosamine and anhydrous$\mathrm{D}$-glucosamine. It is soluble at $\mathrm{pH}<6$ and forms gel structure by ionotropic gelation. Chitosan can further polymerize by means of cross-linking formation in the presence of anions and polyanions [202]. It is used for coating of gelatin capsules, because its efficiency for the increasing viability of probiotic cells is not satisfactory; it is most often used as coat/shell but not capsule.

4.3. Use of Starch for Encapsulation of Probiotics. Starch consists of D-glucose unit joint together with glycosidic bonds. It has been used as a material for coating of alginate capsules. High-amylose corn starch (HACS) can be applied for enhancing functions of capsule or shell/coat formation [183]. Lyophilized corn starch (LCS) has been reported to be used as capsule-forming material; however, it decomposes after being subjected to pancreatic enzymes [234]. Resistant starch (RS) is not degraded by the pancreatic amylase. His specification apart from giving the microbeads good enteric delivery characteristic also gives them probiotic functionality as they can be used by the probiotic bacteria in the intestine [235]. The incorporation of Hi-Maize starch improved the 




FIGURE 8: Schematic presentation of the spray coating technology.

TABLE 11: Advantages and disadvantages of coacervation technique.

Advantages

(i) The advantages are high payload (99\%) and controls the release of core material [146]

(ii) The process can be carried out at room temperature making it particularly suitable for heat sensitive probiotic bacteria [26]

\section{Disadvantages}

(i) The disadvantages are high cost of the particle isolation procedure and complexity of technique

(ii) But it was suggested that the optimization of the last step and use of spray dryer instead of fluidized or freeze dryer can reduce the overall cost [146] encapsulation of viable bacteria compared with the bacteria encapsulated without starch [140, 236].

4.4. Use of Xanthan-Gellan Gum for Encapsulation of Probiotics. Gellan gum is an anionic polysaccharide derived from Sphingomonas elodea which is constituted of a repeating unit of four monomers that are glucose, glucuronic acid, glucose, and rhamnose [22]. Xanthan is an exopolysaccharide derived from Xanthomonas campestris. The optimum mixing proportion for xanthan-gellan gum is $1: 0.75$ [32]. In contrary with alginate, this mixture is resistant to acidic conditions $[32,181]$.

4.5. Use of $\kappa$-Carrageenan for Encapsulation of Probiotics. Carrageenan is polymer having linear structure consisting of D-galactose units alternatively linked by $\alpha$-(1-3) and $\beta$ (14 ) bonds. Types of carrageenan are kappa $(\kappa)$, iota $(\iota)$, and lambda $(\lambda)$ [237]. Monosulfated $\kappa$-carrageenan and bisulfated l-carrageenan contain oxygen bridge between 3 and 6 of the D-galactose, which is responsible for the conformational transition and gelatin. The $\lambda$-carrageenan is trisulfated and does not have this bridge required for gel formation [238]. Carrageenan gelatin is induced by temperature changes. A rise in temperature $\left(60-80^{\circ} \mathrm{C}\right)$ is required to dissolve it, and gelation occurs by cooling to room temperature [238, 239], and then microparticles are stabilized by adding potassium ion [29]. It is commonly used as a food additive; its safety has been approved by several government agencies including
FDA, Codex Alimentarius, and the joint FAO/WHO food additive [240]. It has good capacity to form gels that can entrap the cell. However, the cell slurry should be added to the heat sterilized suspension between $40-45^{\circ} \mathrm{C}$; otherwise the gel hardens at room temperature [241]. Usually it is used in concentration such as $2-5 \%$ [242]. The encapsulation of probiotic cell in $\kappa$-carrageenan beads keeps the bacteria in a viable state [169], but the produced gels are brittle and do not withstand stresses [22].

\subsection{Use of Various Proteins-Based Coating for Encapsulation of Probiotics}

4.6.1. Gelatin. Gelatin is used as a thermally reversible gelling agent for encapsulation. Because of its amphoteric nature, it is an excellent candidate to incorporate with anionic-gelforming polysaccharides, such as gellan gum.

It is frequently used in food and pharmaceutical industries [243]. It is a protein derived by partial hydrolysis of collagen of animal origin. It has versatile functional properties, and forms a solution of high viscosity in water which set to a gel on cooling.

4.6.2. Milk Protein. Milk proteins are natural vehicles for probiotic cells, and owing to their structural and physicochemical properties, they can be used as a delivery system [217]. The results of these studies are promising, and using milk proteins is an interesting way because of their biocompatibility [217]. 
TABLE 12: Advantages and disadvantages of cocrystallization.

\begin{tabular}{ll}
\hline Advantages & Disadvantages \\
\hline $\begin{array}{l}\text { The advantages are economical with high payload (90\%). It is } \\
\text { utilized in the confectionery and pharmaceutical industries }\end{array}$ & $\begin{array}{l}\text { Disadvantages are higher control rate of nucleation, crystallization, } \\
\text { and thermal balance during operation [26] }\end{array}$ \\
\hline
\end{tabular}

TABLE 13: Advantages and disadvantages of alginate system.

\begin{tabular}{|c|c|}
\hline Advantages & Disadvantages \\
\hline $\begin{array}{l}\text { (i) The advantages are easy formation of gel matrices } \\
\text { around bacterial cells, being nontoxic and cheap; mild } \\
\text { process conditions are needed for their performance, } \\
\text { easily prepared and performed and properly resolved in } \\
\text { the intestine and release entrapped cell }[85,146,201] \\
\text { (ii) Alginate gel matrix forms bacterial cell beads with a } \\
\text { diameter of } 1-3 \mu \mathrm{m} \text {, and the pore size does not exceed } \\
7 \mathrm{NM} \text { [202] }\end{array}$ & $\begin{array}{l}\text { (i) Disadvantages are susceptible to acidic environments, crackling and } \\
\text { loss of mechanical stability in lactic acid [203,204], difficulties in } \\
\text { industrial scale applications due to their high expenses, and a weak } \\
\text { ability of scaling up as well as the formation of crackled and porous bead } \\
\text { surfaces, which leads to fast diffusion of moisture and fluids through } \\
\text { capsules which reduces their barrier properties against unfavorable } \\
\text { environment factor [146] } \\
\text { (ii) This can be overcome by blending of alginate with another polymer } \\
\text { like starch, coating other compound on its capsules }[29,30,32,181]\end{array}$ \\
\hline
\end{tabular}

4.6.3. Whey Protein. It easily heats denatured which affect aggregation and reduction in emulsion stability. Whey proteins are heat sensitive and show inferior surface activities. Whey protein appears as a potential candidate as coating agent as it is entirely biodegradable and frequently used in many types of food products.

The protein matrixes have different cell release properties than the other microencapsulation methods (polymer or fat based). Thus, applications are also extended to other foods for protection during processing as well as stability during storage but also in nutraceutical for protection and soil release in the GI tract [244].

4.7. Use of Cellulose Acetate Phthalate (CAP) for Encapsulation of Probiotics. Because of its safe nature, CAP is used for controlling drug release in the intestine [23]. It is not soluble at $\mathrm{pH}$ less than 5 but it is soluble at $\mathrm{pH}$ higher than 6 [236]. This property is essential for probiotic encapsulation because the bilateral must not dissolve in the stomach but only in the gut. The disadvantage of CAP is that it cannot form gel beads by ionotropic gelation so capsules have been developed by emulsification. CAP is widely used as a coating agent because it provides better protection for microorganisms in simulated GI conditions [191].

4.8. Criteria to Select a Proper Encapsulation Technology. When one chooses encapsulation as a technology to deliver the desired benefits, one should consider carefully the design of the encapsulation.

(i) What are the physicochemical characteristics of the active?

(ii) Which processing conditions are used during food production or processing?

(iii) How will the encapsulates be stored prior to use?

(iv) What will be the storage conditions of the food product containing the encapsulates prior to consumer use? (v) Which particle size and density are needed to have it incorporated properly in the food product?

(vi) What are the trigger(s) and mechanism(s) of release?

(vii) What are the cost constraints?

\section{Conclusion and Future Perspective}

In the present article, principle, methods, and materials used in the encapsulation of probiotic cells are discussed. The advances in this field have been tremendous with nutraceutical and food ingredients. However, as to the microencapsulation of live probiotic bacterial cells, the technology seems to be not well developed. The delivery of viable microencapsulated probiotic bacteria will become important in near future. Any type of triggers can be used to prompt the release of encapsulated ingredients, such as $\mathrm{pH}$ changes, mechanical stress, temperature, enzymatic activity, time, and osmotic force. The challenges are to select the appropriate encapsulation technique and encapsulating materials. One important challenge for cell encapsulation is the largest size of microbial cells (typically $1-4 \mu \mathrm{m}$ ) or particles of freezedried culture (more than $100 \mathrm{~mm}$ ). This characteristic limits cell loading for small capsules or, when large size capsules are produced, can negatively affect the textural and sensorial properties of food products in which they are added. In almost all cases, gel entrapment using natural polymers, such as calcium alginate, carrageenan, gellan gum, and Chitosan, is favored by researchers. However, despite promising on a laboratory scale, the developed technologies for producing gel beads still present serious difficulties for large-scale production of food grade microencapsulated microorganisms.

Another major challenge is to improve the viability of probiotics during the manufacturing processes, particularly heat processing. Consequently, there appears to be no commercial probiotic products available that are stable at high temperatures. Keeping in view the importance of producing thermoresistant probiotic microorganisms, as well as the interests of food and pharmaceutical companies, new 
approaches are needed in further research. There are at least two options: (1) discovering new strains of probiotic bacteria that are naturally heat stable or that have been genetically modified and (2) developing an encapsulation system that effectively acts like an "insulation material."

\section{Conflict of Interests}

The authors have no conflict of interests.

\section{Acknowledgments}

The authors wish to thank the reviewers for making valuable comments on this paper. They also wish to thank the Dr. Girish K. Jani, Principal, S.S.R College of Pharmacy, Silvassa, for providing digital library for referencing.

\section{References}

[1] FAO/WHO, Guidelines for the Evaluation of Probiotics in Food, Food and Agriculture Organization of the United Nations/World Health Organization, London, UK, 2002.

[2] R. Fuller, "Probiotics in man and animals," Journal of Applied Bacteriology, vol. 66, no. 5, pp. 365-378, 1989.

[3] S. Rokka and P. Rantamäki, "Protecting probiotic bacteria by microencapsulation: challenges for industrial applications," European Food Research and Technology, vol. 231, no. 1, pp. 1-12, 2010.

[4] C. Dunne, "Adaptation of bacteria to the intestinal niche: probiotics and gut disorder," Inflammatory Bowel Diseases, vol. 7, no. 2, pp. 136-145, 2001.

[5] R. Agheyisi, "Ga-121 probiotics: ingredients, supplements, foods," Tech. Rep., Business Communication Company, Norwalk, Conn, USA, 2005.

[6] S. K. Hood and E. A. Zottola, "Effect of low pH on the ability of Lactobacillus-acidophilus to survive and adhere to human intestinal cells," Journal of Food Science, vol. 53, no. 5, pp. 15141516, 1988.

[7] F. A. M. Klaver, F. Kingma, and A. H. Weerkamp, "Growth and survival of bifidobacteria in milk," Netherlands Milk and Dairy Journal, vol. 47, no. 3-4, pp. 151-164, 1993.

[8] N. P. Shah and W. E. V. Lankaputhra, "Improving viability of Lactobacillus acidophilus and Bifidobacterium spp. in yogurt," International Dairy Journal, vol. 7, no. 5, pp. 349-356, 1997.

[9] D. B. Hughes and D. G. Hoover, "Bifidobacteria: their potential for use in American dairy products," Food Technology, vol. 45, no. 4, pp. 74-83, 1991.

[10] C. Desmond, C. Stanton, G. F. Fitzgerald, K. Collins, and R. P. Ross, "Environmental adaptation of probiotic lactobacilli towards improvement of performance during spray drying," International Dairy Journal, vol. 12, no. 2-3, pp. 183-190, 2012.

[11] A. K. Anal and H. Singh, "Recent advances in microencapsulation of probiotics for industrial applications and targeted delivery," Trends in Food Science and Technology, vol. 18, pp. 240-251, 2007.

[12] W. Krasaekoopt, B. Bhandari, and H. Deeth, "The influence of coating materials on some properties of alginate beads and survivability of microencapsulated probiotic bacteria," International Dairy Journal, vol. 14, no. 8, pp. 737-743, 2004.
[13] P. Capela, T. K. C. Hay, and N. P. Shah, "Effect of cryoprotectants, prebiotics and microencapsulation on survival of probiotic organisms in yoghurt and freeze-dried yoghurt," Food Research International, vol. 39, no. 2, pp. 203-211, 2006.

[14] K. N. Chen, M. J. Chen, and C. W. Lin, "Optimal combination of the encapsulating materials for probiotic microcapsules and its experimental verification (R1)," Journal of Food Engineering, vol. 79, pp. 313-320, 2006.

[15] N. T. Annan, A. D. Borza, and L. T. Hansen, "Encapsulation in alginate-coated gelatin microspheres improves survival of the probiotic Bifidobacterium adolescentis $15703 \mathrm{~T}$ during exposure to simulated gastro-intestinal conditions," Food Research International, vol. 41, no. 2, pp. 184-193, 2008.

[16] G. K. Gbassi, T. Vandamme, S. Ennahar, and E. Marchioni, "Microencapsulation of Lactobacillus plantarum spp in an alginate matrix coated with whey proteins," International Journal of Food Microbiology, vol. 129, no. 1, pp. 103-105, 2009.

[17] T. Heidebach, P. Först, and U. Kulozik, "Influence of caseinbased microencapsulation on freeze-drying and storage of probiotic cells," Journal of Food Engineering, vol. 98, no. 3, pp. 309-316, 2010.

[18] O. Sandoval-Castilla, C. Lobato-Calleros, H. S. García-Galindo, J. Alvarez-Ramírez, and E. J. Vernon-Carter, "Textural properties of alginate-pectin beads and survivability of entrapped Lb. casei in simulated gastrointestinal conditions and in yoghurt," Food Research International, vol. 43, no. 1, pp. 111-117, 2010.

[19] B. F. Gibbs, S. Kermasha, I. Alli, and C. N. Mulligan, "Encapsulation in the food industry: a review," International Journal of Food Sciences and Nutrition, vol. 50, no. 3, pp. 213-224, 1999.

[20] C. P. Champagne and K. Kailasapathy, "Encapsulation of probiotics," in Delivery and Controlled Release of Bioactives in Foods and Nutraceuticals, N. Garti, Ed., pp. 344-369, Woodhead, Cambridge, UK, 2008.

[21] N. J. Zuidam and E. Shimoni, "Overview of microencapsulates for use in food products or processes and methods to take them," in Encapsulation Technologies for Active Food Ingredients and Food Processing, N. J. Zuidam and V. Nedovic, Eds., pp. 329, Springer, New York, NY, USA, 2009.

[22] M. J. Chen and K. N. Chen, "Applications of probiotic encapsulation in dairy products," in Encapsulation and Controlled Release Technologies in Food Systems, J. M. Lakkis, Ed., pp. 83107, Wiley-Blackwell, New York, NY, USA, 2007.

[23] A. Mortazavian, S. H. Razavi, M. R. Ehsani, and S. Sohrabvandi, "Principle's and method of microencapsulation of probiotic microorganisms," Iranian Journal of Biotechnology, vol. 5, no. 1, pp. 1-18, 2007.

[24] P. Muthukumarasamy, P. Allan-Wojtas, and R. A. Holley, "Stability of Lactobacillus reuteri in different types of microcapsules," Journal of Food Science, vol. 71, no. 1, pp. M20-M24, 2006.

[25] A. Ainsley Reid, J. C. Vuillemard, M. Britten, Y. Arcand, E. Farnworth, and C. P. Champagne, "Microentrapment of probiotic bacteria in a $\mathrm{Ca}^{2+}$-induced whey protein gel and effects on their viability in a dynamic gastro-intestinal model," Journal of Microencapsulation, vol. 22, no. 6, pp. 603-619, 2005.

[26] K. G. H. Desai and H. J. Park, "Recent developments in microencapsulation of food ingredients," Drying Technology, vol. 23, no. 7, pp. 1361-1394, 2005.

[27] T. Y. Sheu and R. T. Marshall, "Microencapsulation of lactobacilli in calcium alginate gels," Journal of Food Science, vol. 54, pp. 557-561, 1993. 
[28] K. M. K. Kebary, S. A. Hussein, and R. M. Badawi, "Improving viability of Bifidobacteria and their effect on frozen ice milk," Egyptian Journal of Dairy Science, vol. 23, pp. 319-337, 1998.

[29] W. Krasaekoopt, B. Bhandari, and H. Deeth, "Evaluation of encapsulation techniques of probiotics for yoghurt," International Dairy Journal, vol. 13, no. 1, pp. 3-13, 2003.

[30] H. L. Truelstrup, P. M. Allan-Wojtas, Y. L. Jin, and A. T. Paulson, "Survival of Ca-alginate microencapsulated Bifidobacterium spp. in milk and simulated gastrointestinal conditions," Food Microbiology, vol. 19, no. 1, pp. 35-45, 2002.

[31] M. Borgogna, B. Bellich, L. Zorzin, R. Lapasin, and A. Cesàro, "Food microencapsulation of bioactive compounds: rheological and thermal characterisation of nonconventional gelling system," Food Chemistry, vol. 122, no. 2, pp. 416-423, 2010.

[32] W. Sun and M. W. Griffiths, "Survival of bifidobacteria in yogurt and simulated gastric juice following immobilization in gellanxanthan beads," International Journal of Food Microbiology, vol. 61, no. 1, pp. 17-25, 2000.

[33] J. C. Mohan, R. Arora, and M. Khalilullah, "Short term hypolipidemic effects of oral Lactobacillus sporogenes therapy in patients with primary dyslipidemias," Indian Heart Journal, vol. 42, no. 5, pp. 361-364, 1990.

[34] H. Bukowska, J. Pieczul-Mroz, M. Jastrzebska, K. Chelstowski, and M. Naruszewicz, "Decrease in fibrinogen and LDLcholesterol levels upon supplementation of diet with Lactobacillus plantarum in subjects with moderately elevated cholesterol," Atherosclerosis, vol. 137, no. 2, pp. 437-438, 1998.

[35] J. W. Anderson and S. E. Gilliland, "Effect of fermented milk (yogurt) containing Lactobacillus acidophilus L1 on serum cholesterol in hypercholesterolemic humans," Journal of the American College of Nutrition, vol. 18, no. 1, pp. 43-50, 1999.

[36] M. Naruszewicz, M. Johansson, D. Zapolska-Downar, and H. Bukowska, "Effect of Lactobacillus plantarum 299v on cardiovascular disease risk factors in smokers," American Journal of Clinical Nutrition, vol. 76, no. 6, pp. 1249-1255, 2002.

[37] M. Kalliomäki, S. Salminen, H. Arvilommi, P. Kero, P. Koskinen, and E. Isolauri, "Probiotics in primary prevention of atopic disease: a randomised placebo-controlled trial," The Lancet, vol. 357, no. 9262, pp. 1076-1079, 2001.

[38] S. Rautava, M. Kalliomäki, and E. Isolauri, "Probiotics during pregnancy and breast-feeding might confer immunomodulatory protection against atopic disease in the infant," Journal of Allergy and Clinical Immunology, vol. 109, no. 1, pp. 119-121, 2002.

[39] T. Pessi, Y. Sütas, M. Hurme, and E. Isolauri, "Interleukin10 generation in atopic children following oral lactobacillus rhamnosus GG," Clinical and Experimental Allergy, vol. 30, no. 12, pp. 1804-1808, 2000.

[40] E. Isolauri, T. Arvola, Y. Sutas, E. Moilanen, and S. Salminen, "Probiotics in the management of atopic eczema," Clinical and Experimental Allergy, vol. 30, no. 11, pp. 1604-1610, 2000.

[41] E. Isolauri, H. Majamaa, T. Arvola, I. Rantala, E. Virtanen, and H. Arvilommi, "Lactobacillus casei strain GG reverses increased intestinal permeability induced by cow milk in suckling rats," Gastroenterology, vol. 105, no. 6, pp. 1643-1650, 1993.

[42] T. Pessi, Y. Sütas, A. Marttinen, and E. Isolauri, "Probiotics reinforce mucosal degradation of antigens in rats: implications for therapeutic use of probiotics," Journal of Nutrition, vol. 128, no. 12, pp. 2313-2318, 1998.

[43] T. Matsuzaki, R. Yamazaki, S. Hashimoto, and T. Yokokura, "The effect of oral feeding of Lactobacillus casei strain Shirota on immunoglobulin E production in mice," Journal of Dairy Science, vol. 81, no. 1, pp. 48-53, 1998.

[44] K. Shida, K. Makino, A. Morishita et al., "Lactobacillus casei inhibits antigen-induced IgE secretion through regulation of cytokine production in murine splenocyte cultures," International Archives of Allergy and Immunology, vol. 115, no. 4, pp. 278-287, 1998.

[45] H. Majamaa and E. Isolauri, "Probiotics: a novel approach in the management of food allergy," Journal of Allergy and Clinical Immunology, vol. 99, no. 2, pp. 179-185, 1997.

[46] L. Pelto, E. Isolauri, E.-M. Lillus, J. Nuutila, and S. Salminen, "Probiotic bacteria down-regulate the milk-induced inflammatory response in milk-hypersensitive subjects but have an immunostimulatory effect in healthy subjects," Clinical and Experimental Allergy, vol. 28, no. 12, pp. 1474-1479, 1998.

[47] Y. Sütas, M. Hurme, and E. Isolauri, "Down-regulation of anti-CD3 antibody-induced IL-4 production by bovine caseins hydrolysed with Lactobacillus GG-derived enzymes," Scandinavian Journal of Immunology, vol. 43, no. 6, pp. 687-689, 1996.

[48] Y. Sütas, E. Soppi, H. Korhonen et al., "Suppression of lymphocyte proliferation in vitro by bovine caseins hydrolyzed with Lactobacillus casei GG-derived enzymes," Journal of Allergy and Clinical Immunology, vol. 98, no. 1, pp. 216-224, 1996.

[49] L. Pelto, S. Salminen, and E. Isolauri, "Lactobacillus GG modulates milkinduced immune inflammatory response in milkhypersensitive adults," Nutrition Today, vol. 31, supplement 6, pp. 45S-47S, 1996.

[50] K. Hatakka, E. Savilahti, A. Pönkä et al., "Effect of long term consumption of probiotic milk on infections in children attending day care centres: double blind, randomised trial," British Medical Journal, vol. 322, no. 7298, pp. 1327-1329, 2001.

[51] E. J. Schiffrin, F. Rochat, H. Link-Amster, J. M. Aeschlimann, and A. Donnet-Hughes, "Immunomodulation of human blood cells following the ingestion of lactic acid bacteria," Journal of Dairy Science, vol. 78, no. 3, pp. 491-497, 1995.

[52] E. J. Schiffrin, D. Brassart, A. L. Servin, F. Rochat, and A. Donnet-Hughes, "Immune modulation of blood leukocytes in humans by lactic acid bacteria: criteria for strain selection," American Journal of Clinical Nutrition, vol. 66, supplement 2, pp. 515S-520S, 1997.

[53] G. Perdigon, M. E. N. de Macias, S. Alvarez, G. Oliver, and A. A. P. Holgado, "Enhancement of immune response in mice fed with Streptococcus thermophilus and Lactobacillus acidophilus," Journal of Dairy Science, vol. 70, no. 5, pp. 919-926, 1993.

[54] M. V. Tejada-Simon, J. H. Lee, Z. Ustunol, and J. J. Pestka, "Ingestion of yogurt containing Lactobacillus acidophilus and Bifidobacterium to potentiate immunoglobulin A responses to cholera toxin in mice," Journal of Dairy Science, vol. 82, no. 4, pp. 649-660, 1999.

[55] G. E. Hatcher and R. S. Lambrecht, "Augmentation of macrophage phagocytic activity by cell-free extracts of selected lactic acid-producing bacteria," Journal of Dairy Science, vol. 76, no. 9, pp. 2485-2492, 1993.

[56] P. Marteau, J. Vaerman, J. Dehennin et al., "Effects of intrajejunal perfusion and chronic ingestion of Lactobacillus johnsonii strain Lal on serum concentrations and jejunal secretions of immunoglobulins and serum proteins in healthy humans," Gastroenterologie Clinique et Biologique, vol. 21, no. 4, pp. 293298, 1997.

[57] K. Arunachalam, H. S. Gill, and R. K. Chandra, "Enhancement of natural immune function by dietary consumption of 
Bifidobacterium lactis (HN019)," European Journal of Clinical Nutrition, vol. 54, no. 3, pp. 263-267, 2000.

[58] B. L. Chiang, Y. H. Sheih, L. H. Wang, C. K. Liao, and H. S. Gill, "Enhancing immunity by dietary consumption of a probiotic lactic acid bacterium (Bifidobacterium lactis HN019): optimization and definition of cellular immune responses," European Journal of Clinical Nutrition, vol. 54, no. 11, pp. 849$855,2000$.

[59] Y.-H. Sheih, B.-L. Chiang, L.-H. Wang, C.-K. Liao, and H. S. Gill, "Systemic immunity-enhancing effects in healthy subjects following dietary consumption of the lactic acid bacterium Lactobacillus rhamnosus HN001," Journal of the American College of Nutrition, vol. 20, no. 2, pp. 149-156, 2001.

[60] H. S. Gill, K. J. Rutherfurd, J. Prasad, and P. K. Gopal, "Enhancement of natural and acquired immunity by Lactobacillus rhamnosus (HN001), Lactobacillus acidophilus (HN017) and Bifidobacterium lactis (HN019)," British Journal of Nutrition, vol. 83, no. 2, pp. 167-176, 2000.

[61] A. Armuzzi, F. Cremonini, F. Bartolozzi et al., "The effect of oral administration of Lactobacillus GG on antibiotic-associated gastrointestinal side-effects during Helicobacter pylori eradication therapy," Alimentary Pharmacology and Therapeutics, vol. 15 , no. 2, pp. 163-169, 2001.

[62] J. A. Vanderhoof, D. B. Whitney, D. L. Antonson, T. L. Hanner, J. V. Lupo, and R. J. Young, "Lactobacillus GG in the prevention of antibiotic-associated diarrhea in children," Journal of Pediatrics, vol. 135, no. 5, pp. 564-568, 1999.

[63] S. Siitonen, H. Vapaatalo, S. Salminen et al., "Effect of Lactobacillus GG yoghurt in prevention of antibiotic associated diarrhoea," Annals of Medicine, vol. 22, no. 1, pp. 57-59, 1990.

[64] J. A. Biller, A. J. Katz, A. F. Flores, T. M. Buie, and S. L. Gorbach, "Treatment of recurrent Clostridium difficile colitis with Lactobacillus GG," Journal of Pediatric Gastroenterology and Nutrition, vol. 21, no. 2, pp. 224-226, 1995.

[65] R. G. Bennett, S. L. Gorbach, B. R. Goldin et al., "Treatment of relapsing Clostridium difficile diarrhea with Lactobacillus GG," Nutrition Today, vol. 31, pp. 35S-39S, 1996.

[66] F. Black, K. Einarsson, A. Lidbeck, K. Orrhage, and C. E. Nord, "Effect of lactic acid producing bacteria on the human intestinal microflora during ampicillin treatment," Scandinavian Journal of Infectious Diseases, vol. 23, no. 2, pp. 247-254, 1991.

[67] M. Hickson, A. L. D'Souza, N. Muthu et al., "Use of probiotic Lactobacillus preparation to prevent diarrhoea associated with antibiotics: randomised double blind placebo controlled trial," British Medical Journal, vol. 335, article 80, 2007.

[68] C. M. Surawicz, G. W. Elmer, P. Speelman, L. V. McFarland, J. Chinn, and G. van Belle, "Prevention of antibiotic-associated diarrhea by Saccharomyces boulardii: a prospective study," Gastroenterology, vol. 96, no. 4, pp. 981-988, 1989.

[69] L. V. McFarland, C. M. Surawicz, R. N. Greenberg et al., "Prevention of $\beta$-lactam-associated diarrhea by Saccharomyces boulardii compared with placebo," American Journal of Gastroenterology, vol. 90, no. 3, pp. 439-448, 1995.

[70] F. Cremonini, S. Di Caro, M. Covino et al., "Effect of different probiotic preparations on anti-Helicobacter pylori therapyrelated side effects: a parallel group, triple blind, placebocontrolled study," American Journal of Gastroenterology, vol. 97, no. 11, pp. 2744-2749, 2002.

[71] T. Arvola, K. Laiho, S. Torkkeli et al., "Prophylactic Lactobacillus GG reduces antibiotic-associated diarrhea in children with respiratory infections: a randomized study," Pediatrics, vol. 104, no. 5, pp. 1-4, 1999.
[72] J. Levy, "Experience with live Lactobacillus plantarum 299V: a promising adjunct in the management of recurrent Clostridium difficile infection," Gastroenterology, vol. 112, article A379, 1997.

[73] M. Gotteland, S. Cruchet, and S. Verbeke, "Effect of lactobacillus ingestion on the gastrointestinal mucosal barrier alterations induced by indometacin in humans," Alimentary Pharmacology and Therapeutics, vol. 15, no. 1, pp. 11-17, 2001.

[74] H. Jahn, R. Ullrich, T. Schneider et al., "Immunological and trophical effects of Saccharomyces boulardii on the small intestine in healthy human volunteers," Digestion, vol. 57, no. 2, pp. 95-104, 1996.

[75] J.-P. Buts, N. de Keyser, and L. de Raedemaeker, "Saccharomyces boulardii enhances rat intestinal enzyme expression by endoluminal release of polyamines," Pediatric Research, vol. 36, no. 4, pp. 522-527, 1994.

[76] A. Shornikova, I. A. Casas, H. Mykkänen, E. Salo, and T. Vesikari, "Bacteriotherapy with Lactobacillus reuteri in rotavirus gastroenteritis," Pediatric Infectious Disease Journal, vol. 16, no. 12, pp. 1103-1107, 1997.

[77] D. R. Mack, S. Michail, S. Wei, L. McDougall, and M. A. Hollingsworth, "Probiotics inhibit enteropathogenic E. coli adherence in vitro by inducing intestinal mucin gene expression," American Journal of Physiology, vol. 276, no. 4, pp. G941G950, 1999.

[78] A.-V. Shornikova, E. Isolauri, L. Burkanova, S. Lukovnikova, and T. Vesikari, "A trial in the Karelian Republic of oral rehydration and Lactobacillus GG for treatment of acute diarrhoea," Acta Paediatrica, International Journal of Paediatrics, vol. 86, no. 5, pp. 460-465, 1997.

[79] M. Kaila, E. Isolauri, E. Soppi, E. Virtanen, S. Laine, and H. Arvilommi, "Enhancement of the circulating antibody secreting cell response in human diarrhea by a human Lactobacillus strain," Pediatric Research, vol. 32, no. 2, pp. 141-144, 1992.

[80] J. M. Saavedra, N. A. Bauman, I. Oung, J. A. Perman, and R. H. Yolken, "Feeding of Bifidobacterium bifidum and Streptococcus thermophilus to infants in hospital for prevention of diarrhoea and shedding of rotavirus," The Lancet, vol. 344, no. 8929, pp. 1046-1049, 1994.

[81] S. Gonzalez, G. Albarracin, M. L. Pesce, M. Appela, A. P. Holgado, and G. Oliver, "Prevention of infantile diarrhoea by fermented milk," Microbiologie, Aliments, Nutrition, vol. 8, pp. 349-354, 1990.

[82] S. N. Gonzalez, R. Cardozo, M. C. Apella, and G. Oliver, "Biotherapeutic role of fermented milk," Biotherapy, vol. 8, no. 2, pp. 129-134, 1994.

[83] T. Sugita and M. Togowa, "Efficacy of Lactobacillus preparation Biolactis powder in children with rotavirus enteritis," Japan Journal of Pediatrics, vol. 47, pp. 213-220, 1994.

[84] S. Michail and F. Abernathy, "Lactobacillus plantarum reduces the in vitro secretory response of intestinal epithelial cells to enteropathogenic Escherichia coli infection," Journal of Pediatric Gastroenterology and Nutrition, vol. 35, no. 3, pp. 350-355, 2002.

[85] M. Ogawa, K. Shimizu, K. Nomoto et al., "Protective effect of Lactobacillus casei strain Shirota on Shiga toxin-producing Escherichia coli O157:H7 infection in infant rabbits," Infection and Immunity, vol. 69, no. 2, pp. 1101-1108, 2001.

[86] P. F. Pérez, J. Minnaard, M. Rouvet et al., "Inhibition of Giardia intestinalis by extracellular factors from lactobacilli: an in vitro study," Applied and Environmental Microbiology, vol. 67, no. 312, pp. 5037-5042, 2001.

[87] I. Adlerberth, S. Ahrné, M. Johansson, G. Molin, L. A. Hanson, and A. E. Wold, "A mannose-specific adherence mechanism 
in Lactobacillus plantarum conferring binding to the human colonic cell line HT-29," Applied and Environmental Microbiology, vol. 62, no. 7, pp. 2244-2251, 1996.

[88] M. Silva, N. V. Jacobus, C. Deneke, and S. L. Gorbach, "Antimicrobial substance from a human Lactobacillus strain," Antimicrobial Agents and Chemotherapy, vol. 31, no. 8, pp. 12311233, 1987.

[89] D. Bouglé, N. Roland, F. Lebeurrier, and P. Arhan, "Effect of propionibacteria supplementation on fecal bifidobacteria and segmental colonic transit time in healthy human subjects," Scandinavian Journal of Gastroenterology, vol. 34, no. 2, pp. 144148, 1999.

[90] S. Spanhaak, R. Havenaar, and G. Schaafsma, "The effect of consumption of milk fermented by Lactobacillus casei strain Shirota on the intestinal microflora and immune parameters in humans," European Journal of Clinical Nutrition, vol. 52, no. 12, pp. 899-907, 1998.

[91] M. F. Bernet, D. Brassart, J. R. Neeser, and A. L. Servin, "Lactobacillus acidophilus LA 1 binds to cultured human intestinal cell lines and inhibits cell attachment and cell invasion by enterovirulent bacteria," Gut, vol. 35, no. 4, pp. 483-489, 1994.

[92] M.-L. Johansson, G. Molin, B. Jeppsson, S. Nobaek, S. Ahrne, and S. Bengmark, "Administration of different Lactobacillus strains in fermented oatmeal soup: in vivo colonization of human intestinal mucosa and effect on the indigenous flora," Applied and Environmental Microbiology, vol. 59, no. 1, pp. 1520, 1993.

[93] C. N. Jacobsen, V. R. Nielsen, A. E. Hayford et al., "Screening of probiotic activities of forty-seven strains of Lactobacillus spp. by in vitro techniques and evaluation of the colonization ability of five selected strains in humans," Applied and Environmental Microbiology, vol. 65, no. 11, pp. 4949-4956, 1999.

[94] R. G. Montes, T. M. Bayless, J. M. Saavedra, and J. A. Perman, "Effect of milks inoculated with Lactobacillus acidophilus or a yogurt starter culture in lactose-maldigesting children," Journal of Dairy Science, vol. 78, no. 8, pp. 1657-1664, 1995.

[95] D. O. Noh and S. E. Gilliland, "Influence of bile on cellular integrity and beta-galactosidase activity of Lactobacillus acidophilus," Journal of Dairy Science, vol. 76, no. 5, pp. 1253-1259, 1993.

[96] M. Y. Lin, D. Savaiano, and S. Harlander, "Influence of nonfermented dairy products containing bacterial starter cultures on lactose maldigestion in humans," Journal of Dairy Science, vol. 74, no. 1, pp. 87-95, 1991.

[97] T. Jiang and D. A. Savaiano, "In vitro lactose fermentation by human colonic bacteria is modified by Lactobacillus acidophilus supplementation," Journal of Nutrition, vol. 127, no. 8, pp. 1489-1495, 1997.

[98] H. S. Kim and S. E. Gilliland, "Lactobacillus acidophilus as a dietary adjunct for milk to aid lactose digestion in humans," Journal of Dairy Science, vol. 66, no. 5, pp. 959-966, 1983.

[99] J. Rasic, I. Klem, D. Jovanovic, and M. Ac, "Antimicrobial effect of Lactobacillus acidophilus and Lactobacillus delbrueckii subsp. bulgaricus against Heelicobacter pylori in vitro," Archives of Gastroenterohepatology, vol. 14, no. 4, pp. 158-160, 1995.

[100] P. Michetti, G. Dorta, P. H. Wiesel et al., "Effect of whey-based culture supernatant of Lactobacillus acidophilus (johnsonii) Lal on Helicobacter pylori infection in humans," Digestion, vol. 60, no. 3, pp. 203-209, 1999.

[101] C. P. Felley, I. Corthésy-Theulaz, J.-L. Rivero et al., "Favourable effect of an acidified milk (LC-1) on Helicobacter pylori gastritis in man," European Journal of Gastroenterology and Hepatology, vol. 13, no. 1, pp. 25-29, 1999.

[102] M. Coconnier, V. Lievin, E. Hemery, and A. L. Servin, "Antagonistic activity against Helicobacter infection in vitro and in vivo by the human Lactobacillus acidophilus strain LB," Applied and Environmental Microbiology, vol. 64, no. 11, pp. 4573-4580, 1998.

[103] K. Niedzielin, H. Kordecki, and B. Birkenfeld, "A controlled, double-blind, randomized study on the efficacy of Lactobacillus plantarum 299V in patients with irritable bowel syndrome," European Journal of Gastroenterology and Hepatology, vol. 13, no. 10, pp. 1143-1147, 2001.

[104] S. Nobaek, M. Johansson, G. Molin, S. Ahrné, and B. Jeppsson, "Alteration of intestinal microflora is associated with reduction in abdominal bloating and pain in patients with irritable bowel syndrome," American Journal of Gastroenterology, vol. 95, no. 5, pp. 1231-1238, 2000.

[105] G. . Bazzocchi, M. Campieri, P. Gionchetti et al., "Change in colonic function and fecal microbiological and enzymatic activities induced by a new probiotic preparation," Gastroenterology International, vol. 11, supplement 1, article 111, 1998.

[106] E. Salminen, I. Elomaa, J. Minkkinen, H. Vapaatalo, and S. Salminen, "Preservation of intestinal integrity during radiotherapy using live Lactobacillus acidophilus cultures," Clinical Radiology, vol. 39, no. 4, pp. 435-437, 1988.

[107] P. Delia, G. Sansotta, V. Donato et al., "Prevention of radiationinduced diarrhea with the use of VSL\#3, a new high-potency probiotic preparation," American Journal of Gastroenterology, vol. 97, no. 8, pp. 2150-2152, 2002.

[108] P. J. Oksanen, S. Salminen, M. Saxelin et al., "Prevention of travellers' diarrhoea by Lactobacillus GG," Annals of Medicine, vol. 22, no. 1, pp. 53-56, 1990.

[109] A. C. Ouwehand, P. V. Kirjavainen, C. Shortt, and S. Salminen, "Probiotics: mechanisms and established effects," International Dairy Journal, vol. 9, no. 1, pp. 43-52, 1999.

[110] G. W. Elmer, C. M. Surawicz, and L. V. McFarland, "Biotherapeutic agents: a neglected modality for the treatment and prevention of selected intestinal and vaginal infections," Journal of the American Medical Association, vol. 275, no. 11, pp. 870876, 1996.

[111] M. Malin, H. Suomalainen, M. Saxelin, and E. Isolauri, "Promotion of $\operatorname{IgA}$ immune response in patients with Crohn's disease by oral bacteriotherapy with Lactobacillus GG," Annals of Nutrition and Metabolism, vol. 40, no. 3, pp. 137-145, 1996.

[112] P. Gupta, H. Andrew, B. S. Kirschner, and S. Guandalini, "Is Lactobacillus GG helpful in children with Crohn's disease? Results of a preliminary, open-label study," Journal of Pediatric Gastroenterology and Nutrition, vol. 31, no. 4, pp. 453-457, 2000.

[113] M. Guslandi, G. Mezzi, M. Sorghi, and P. A. Testoni, "Saccharomyces boulardii in maintenance treatment of Crohn's disease," Digestive Diseases and Sciences, vol. 45, no. 7, pp. 1462$1464,2000$.

[114] K. Plein and J. Hotz, "Therapeutic effects of Saccharomyces boulardii on mild residual symptoms in a stable phase of Crohn's disease with special respect to chronic diarrhea-a pilot study," Zeitschrift fur Gastroenterologie, vol. 31, no. 2, pp. 129134, 1993.

[115] A. Venturi, P. Gionchetti, F. Rizzello et al., "Impact on the composition of the faecal flora by a new probiotic preparation: preliminary data on maintenance treatment of patients with ulcerative colitis," Alimentary Pharmacology and Therapeutics, vol. 13, no. 8, pp. 1103-1108, 1999. 
[116] W. Kruis, E. Schutz, P. Fric, B. Fixa, G. Judmaier, and M. Stolte, "Double-blind comparison of an oral Escherichia coli prepration and mesalazine in maintaining remission of ulcerative colitis," Alimentary Pharmacology and Therapeutics, vol. 11, no. 5, pp. 853-858, 1997.

[117] B. J. Rembacken, A. M. Snelling, P. M. Hawkey, D. M. Chalmers, and A. T. R. Axon, "Non-pathogenic Escherichia coli versus mesalazine for the treatment of ulcerative colitis: a randomised trial," The Lancet, vol. 354, no. 9179, pp. 635-639, 1999.

[118] P. Gionchetti, F. Rizzello, A. Venturi et al., "Oral bacteriotherapy as maintenance treatment in patients with chronic pouchitis: a double-blind, placebo-controlled trial," Gastroenterology, vol. 119 , no. 2, pp. 584-587, 2000.

[119] R. J. Kennedy, S. J. Kirk, and K. R. Gardiner, "Probiotics in IBD," Gut, vol. 49, no. 6, p. 873, 2001.

[120] W. H. L. Ling, R. Korpela, H. Mykkanen, S. Salminen, and O. Hanninen, "Lactobacillus strain GG supplementation decreases colonic hydrolytic and reductive enzyme activities in healthy female adults," Journal of Nutrition, vol. 124, no. 1, pp. 18-23, 1994.

[121] P. Bailey and K. Shahani, "Inhibitory effect of acidophilus cultured colostrum and milk upon the proliferation of ascites tumor," in Proceedings of the 71st Annual Meeting of the American Dairy Science Association, 1979.

[122] G. H. McIntosh, P. J. Royle, and M. J. Playne, "A probiotic strain of L. Acidophilus reduces DMH-induced large intestinal tumors in male sprague-dawley rats," Nutrition and Cancer, vol. 35, no. 2, pp. 153-159, 1999.

[123] B. R. Goldin and S. L. Gorbach, "The effect of milk and lactobacillus feeding on human intestinal bacterial enzyme activity," American Journal of Clinical Nutrition, vol. 39, no. 5, pp. 756-761, 1984.

[124] I. G. Bogdanov, P. G. Dalev, and A. I. Gurevich, "Antitumour glycopeptides from Lactobacillus bulgaricus cell wall," FEBS Letters, vol. 57, pp. 3-8, 1975.

[125] G. Reid, A. W. Bruce, and M. Taylor, "Influence of three-day antimicrobial therapy and lactobacillus vaginal suppositories on recurrence or urinary tract infections," Clinical Therapeutics, vol. 14, no. 1, pp. 11-16, 1992.

[126] A. W. Bruce, G. Reid, J. A. McGroarty, M. Taylor, and C. Preston, "Preliminary study on the prevention of recurrent urinary tract infection in adult women using intravaginal Lactobacilli," International Urogynecology Journal, vol. 3, no. 1, pp. 22-25, 1992.

[127] G. Reid, A. W. Bruce, N. Fraser, C. Heinemann, J. Owen, and B. Henning, "Oral probiotics can resolve urogenital infections," FEMS Immunology and Medical Microbiology, vol. 30, no. 1, pp. 49-52, 2001.

[128] G. Reid, "Probiotic therapy and functional foods for the prevention of urinary tract infections: state of the art and science," Current Infectious Disease Reports, vol. 2, pp. 518-522, 2000.

[129] G. Reid and A. W. Bruce, "Selection of Lactobacillus strains for urogenital probiotic applications," Journal of Infectious Diseases, vol. 183, supplement 1, pp. S77-S80, 2001.

[130] G. Reid, A. W. Bruce, R. L. Cook, and M. Llano, "Effect of urogenital flora of antibiotic therapy for urinary tract infection," Scandinavian Journal of Infectious Diseases, vol. 22, no. 1, pp. 4347, 1990.

[131] G. Reid, A. W. Bruce, and M. Taylor, "Instillation of Lactobacillus and stimulation of indigenous organisms to prevent recurrence of urinary tract infections," Microecology and Therapy, vol. 23, pp. 32-45, 1995.
[132] G. Reid, "In vitro testing of Lactobacillus acidophilus $\operatorname{NCFM(TM)~as~a~possible~probiotic~for~the~urogenital~tract,"~}$ International Dairy Journal, vol. 10, no. 5-6, pp. 415-419, 2000.

[133] A. B. Williams, C. Yu, K. Tashima, J. Burgess, and K. Danvers, "Evaluation of two self-care treatments for prevention of vaginal candidiasis in women with HIV," The Journal of the Association of Nurses in AIDS Care, vol. 12, no. 4, pp. 51-57, 2001.

[134] E. Hilton, H. D. Isenberg, P. Alperstein, K. France, and M. T. Borenstein, "Ingestion of yogurt containing Lactobacillus acidophilus as prophylaxis for candidal vaginitis," Annals of Internal Medicine, vol. 116, no. 5, pp. 353-357, 1992.

[135] R. D. Wagner, C. Pierson, T. Warner et al., "Biotherapeutic effects of probiotic bacteria on candidiasis in immunodeficient mice," Infection and Immunity, vol. 65, no. 10, pp. 4165-4172, 1997.

[136] M. Plockova, J. Chumchalova, and J. Tomanova, "Antifungal activity of Lactobacillus acidophilus, $\mathrm{CH} 5$ metabolites," Potravinarske Vedy, vol. 15, no. 1, pp. 39-48, 1997.

[137] E. Hilton, P. Rindos, and H. D. Isenberg, "Lactobacillus GG vaginal suppositories and vaginitis," Journal of Clinical Microbiology, vol. 33, no. 5, p. 1433, 1995.

[138] P. Cadieux, J. Burton, G. Gardiner et al., "Lactobacillus strains and vaginal ecology," Journal of the American Medical Association, vol. 287, no. 15, pp. 1940-1941, 2002.

[139] R. Sridar, M. Nguyen, and K. Kailasapathy, "Studies on the effect of encapsulation on the survival of probiotic microorganisms under high acid and bile conditions," Journal of Food Science and Technology, vol. 40, no. 5, pp. 458-460, 2003.

[140] K. Kailasapathy and L. Masondole, "Survival of free and microencapsulated Lactobacillus acidophilus and Bifidobacterium lactis and their effect on texture of feta cheese," Australian Journal of Dairy Technology, vol. 60, no. 3, pp. 252-258, 2005.

[141] A. Picot and C. Lacroix, "Encapsulation of bifidobacteria in whey protein-based microcapsules and survival in simulated gastrointestinal conditions and in yoghurt," International Dairy Journal, vol. 14, no. 6, pp. 505-515, 2004.

[142] E. S. Chan and Z. Zhang, "Bioencapsulation by compression coating of probiotic bacteria for their protection in an acidic medium," Process Biochemistry, vol. 40, no. 10, pp. 3346-3351, 2005.

[143] R. C. W. Hou, M. Y. Lin, M. M. C. Wang, and J. T. C. Tzen, "Increase of viability of entrapped cells of Lactobacillus delbrueckii ssp. bulgaricus in artificial sesame oil emulsions," Journal of Dairy Science, vol. 86, no. 2, pp. 424-428, 2003.

[144] W. K. Ding and N. P. Shah, "Effect of various encapsulating materials on the stability of probiotic bacteria," Journal of Food Science, vol. 74, no. 2, pp. M100-M107, 2009.

[145] A. Sohail, M. S. Turner, A. Coombes, T. Bostrom, and B. Bhandari, "Survivability of probiotics encapsulated in alginate gel microbeads using a novel impinging aerosols method," International Journal of Food Microbiology, vol. 145, no. 1, pp. 162-168, 2011.

[146] S. Gouin, "Microencapsulation: industrial appraisal of existing technologies and trends," Trends in Food Science and Technology, vol. 15, no. 7-8, pp. 330-347, 2004.

[147] Y. Zhou, E. Martins, A. Groboillot, C. P. Champagne, and R. J. Neufeld, "Spectrophotometric quantification of lactic bacteria in alginate and control of cell release with chitosan coating," Journal of Applied Microbiology, vol. 84, no. 3, pp. 342-348, 1998. 
[148] H. Prevost, C. Divies, and E. Rousseau, "Continuous yoghurt production with Lactobacillus bulgaricus and Streptococcus thermophilus entrapped in Ca-alginate," Biotechnology Letters, vol. 7, no. 4, pp. 247-252, 1985.

[149] H. Prevost and C. Divies, "Fresh fermented cheese production with continuous pre-fermented milk by a mixed culture of mesophilic lactic streptococci entrapped in $\mathrm{Ca}-\mathrm{Al}$ ginate," Biotechnology Letters, vol. 9, no. 11, pp. 789-794, 1987.

[150] L. R. Steenson, T. R. Klaenhammer, and H. E. Swaisgood, "Calcium alginate-immobilized cultures of lactic Streptococci are protected from bacteriophages," Journal of Dairy Science, vol. 70, no. 6, pp. 1121-1127, 1987.

[151] L. Kearney, M. Upton, and A. McLoughlin, "Enhancing the viability of Lactobacillus plantarum inoculum by immobilizing the cells in calcium-alginate beads incorporating cryoprotectants," Applied and Environmental Microbiology, vol. 56, no. 10, pp. 3112-3116, 1990.

[152] H. Prevost and C. Divies, "Cream fermentation by a mixed culture of Lactococci entrapped in two-layer calcium alginate gel beads," Biotechnology Letters, vol. 14, no. 7, pp. 583-588, 1992.

[153] N. Morin, M. Bernier-Cardou, and C. P. Champagne, "Production of Lactococcus lactis biomass by immobilized cell technology," Journal of Industrial Microbiology, vol. 9, no. 2, pp. 131-135, 1992.

[154] C. P. Champagne, F. Girard, and N. Rodrigue, "Production of concentrated suspensions of thermophilic lactic acid bacteria in calcium-alginate beads," International Dairy Journal, vol. 3, no. 3, pp. 257-275, 1993.

[155] R. Cachon and C. Divies, "Localization of Lactococcus lactis ssp lactis bv diacetylactis in alginate gel beads affects biomass density and synthesis of several enzymes involved in lactose and citrate metabolism," Biotechnology Techniques, vol. 7, no. 6, pp. 453-456, 1993.

[156] T. Jankowski, M. Zielinska, and A. Wysakowska, "Encapsulation of lactic acid bacteria with alginate/starch capsules," Biotechnology Techniques, vol. 11, no. 1, pp. 31-34, 1997.

[157] L. D. McMaster, S. A. Kokott, and P. Slatter, "Microencapsulation of Bifidobacterium lactis for incorporation into soft foods," World Journal of Microbiology and Biotechnology, vol. 21, no. 5, pp. 723-728, 2005.

[158] L. D. McMaster, S. A. Kokott, S. J. Reid, and V. R. Abratt, "Use of traditional African fermented beverages as delivery vehicles for Bifidobacterium lactis DSM 10140," International Journal of Food Microbiology, vol. 102, no. 2, pp. 231-237, 2005.

[159] C. P. Champagne, C. Gaudy, D. Poncelet, and R. J. Neufeld, "Lactococcus lactis release from calcium alginate beads," Applied and Environmental Microbiology, vol. 58, no. 5, pp. 1429-1434, 1992.

[160] C. Martoni, J. Bhathena, A. M. Urbanska, and S. Prakash, "Microencapsulated bile salt hydrolase producing Lactobacillus reuteri for oral targeted delivery in the gastrointestinal tract," Applied Microbiology and Biotechnology, vol. 81, no. 2, pp. 225233, 2008.

[161] V. Chandramouli, K. Kailasapathy, P. Peiris, and M. Jones, "An improved method of microencapsulation and its evaluation to protect Lactobacillus spp. in simulated gastric conditions," Journal of Microbiological Methods, vol. 56, no. 1, pp. 27-35, 2004.

[162] S. Graff, J. Chaumeil, P. Boy, R. Lai-Kuen, and C. Charrueau, "Formulations for protecting the probiotic Saccharomyces boulardii from degradation in acidic condition," Biological and Pharmaceutical Bulletin, vol. 31, no. 2, pp. 266-272, 2008.
[163] M. Chen, K. Chen, and Y. Kuo, "Optimal thermotolerance of Bifidobacterium bifidum in gellan-alginate microparticles," Biotechnology and Bioengineering, vol. 98, no. 2, pp. 411-419, 2007.

[164] K. Chen, M. Chen, and C. Lin, "Optimal combination of the encapsulating materials for probiotic microcapsules and its experimental verification (R1)," Journal of Food Engineering, vol. 76, no. 3, pp. 313-320, 2006.

[165] K. Lee and T. Heo, "Survival of Bifidobacterium longum immobilized in calcium alginate beads in simulated gastric juices and bile salt solution," Applied and Environmental Microbiology, vol. 66, no. 2, pp. 869-873, 2000.

[166] P. Muthukumarasamy and R. A. Holley, "Survival of Escherichia coli $\mathrm{O} 157: \mathrm{H} 7$ in dry fermented sausages containing microencapsulated probiotic lactic acid bacteria," Food Microbiology, vol. 24, no. 1, pp. 82-88, 2007.

[167] P. Muthukumarasamy and R. A. Holley, "Microbiological and sensory quality of dry fermented sausages containing alginatemicroencapsulated Lactobacillus reuteri," International Journal of Food Microbiology, vol. 111, no. 2, pp. 164-169, 2006.

[168] K. Kailasapathy, "Survival of free and encapsulated probiotic bacteria and their effect on the sensory properties of yoghurt," Lebensmittel-Wissenschaft und Technologie, vol. 39, no. 10, pp. 1221-1227, 2006.

[169] P. Dinakar and V. V. Mistry, "Growth and viability of Bifidobacterium bifidum in cheddar cheese," Journal of Dairy Science, vol. 77, no. 10, pp. 2854-2864, 1994.

[170] P. Audet, C. Paquin, and C. Lacroix, "Immobilized growing lactic acid bacteria with $\kappa$-carrageenan-locust bean gum gel," Applied Microbiology and Biotechnology, vol. 29, no. 1, pp. 11-18, 1988.

[171] A. V. Rao, N. Shiwnarain, and I. Maharaj, "Survival of microencapsulated Bifidobacterium pseudolongum in simulated gastric and intestinal juices," Canadian Institute of Food Science and Technology Journal, vol. 22, no. 4, pp. 345-349, 1989.

[172] T. Y. Sheu and R. T. Marshall, "Improving culture viability in frozen dairy desserts by microencapsulation," Journal of Dairy Science, vol. 74, supplement 1, article 107, 1991.

[173] J.-P. Arnaud, C. Lacroix, and L. Choplin, "Effect of agitation rate on cell release rate and metabolism during continuous fermentation with entrapped growing-Lactobacillus casei subsp. casei," Biotechnology Techniques, vol. 6, no. 3, pp. 265-270, 1992.

[174] A. F. Groboillot, C. P. Champagne, G. D. Darling, D. Poncelet, and R. J. Neufeld, "Membrane formation by interfacial crosslinking of chitosan for microencapsulation of Lactococcus lactis," Biotechnology and Bioengineering, vol. 42, no. 10, pp. 1157-1163, 1993.

[175] T. Y. Sheu, R. T. Marshall, and H. Heymann, "Improving survival of culture bacteria in frozen desserts by microentrapment," Journal of Dairy Science, vol. 76, no. 7, pp. 1902-1907, 1993.

[176] C. L. Hyndman, A. F. Groboillot, D. Poncelet, C. P. Champagne, and R. J. Neufeld, "Microencapsulation of Lactococcus lactis within cross-linked gelatin membranes," Journal of Chemical Technology and Biotechnology, vol. 56, no. 3, pp. 259-263, 1993.

[177] B. C. Larisch, D. Poncelet, C. P. Champagne, and R. J. Neufeld, "Microencapsulation of Lactococcus lactis subsp. cremoris," Journal of Microencapsulation, vol. 11, no. 2, pp. 189-195, 1994.

[178] S. Mandal, A. K. Puniya, and K. Singh, "Effect of alginate concentrations on survival of microencapsulated Lactobacillus casei NCDC-298," International Dairy Journal, vol. 16, no. 10, pp. 1190-1195, 2006. 
[179] J. S. Lee, D. S. Cha, and H. J. Park, "Survival of freezedried Lactobacillus bulgaricus KFRI 673 in chitosan-coated calcium alginate microparticles," Journal of Agricultural and Food Chemistry, vol. 52, no. 24, pp. 7300-7305, 2004.

[180] A. Homayouni, A. Azizi, M. R. Ehsani, M. S. Yarmand, and S. H. Razavi, "Effect of microencapsulation and resistant starch on the probiotic survival and sensory properties of synbiotic ice cream," Food Chemistry, vol. 111, no. 1, pp. 50-55, 2008.

[181] K. Sultana, G. Godward, N. Reynolds, R. Arumugaswamy, P. Peiris, and K. Kailasapathy, "Encapsulation of probiotic bacteria with alginate-starch and evaluation of survival in simulated gastrointestinal conditions and in yoghurt," International Journal of Food Microbiology, vol. 62, no. 1-2, pp. 47-55, 2000.

[182] N. T. Annan, A. D. Borza, and L. T. Hansen, "Encapsulation in alginate-coated gelatin microspheres improves survival of the probiotic Bifidobacterium adolescentis 15703T during exposure to simulated gastro-intestinal conditions," Food Research International, vol. 41, no. 2, pp. 184-193, 2008.

[183] W. Lian, H. Hsiao, and C. Chou, "Survival of bifidobacteria after spray-drying," International Journal of Food Microbiology, vol. 74, no. 1-2, pp. 79-86, 2002.

[184] W. Lian, H. Hsiao, and C. Chou, "Viability of microencapsulated bifidobacteria in simulated gastric juice and bile solution," International Journal of Food Microbiology, vol. 86, no. 3, pp. 293-301, 2003.

[185] H. Hsiao, W. Lian, and C. Chou, "Effect of packaging conditions and temperature on viability of microencapsulated bifidobacteria during storage," Journal of the Science of Food and Agriculture, vol. 84, no. 2, pp. 134-139, 2004.

[186] G. E. Gardiner, P. Bouchier, E. O'Sullivan et al., "A spray-dried culture for probiotic Cheddar cheese manufacture," International Dairy Journal, vol. 12, no. 9, pp. 749-756, 2002.

[187] E. Ananta, M. Volkert, and D. Knorr, "Cellular injuries and storage stability of spray-dried Lactobacillus rhamnosus GG," International Dairy Journal, vol. 15, no. 4, pp. 399-409, 2005.

[188] A. Picot and C. Lacroix, "Effects of micronization on viability and thermotolerance of probiotic freeze-dried cultures," International Dairy Journal, vol. 13, no. 6, pp. 455-462, 2003.

[189] K. O’Riordan, D. Andrews, K. Buckle, and P. Conway, "Evaluation of microencapsulation of a Bifidobacterium strain with starch as an approach to prolonging viability during storage," Journal of Applied Microbiology, vol. 91, no. 6, pp. 1059-1066, 2001.

[190] L. Su, C. Lin, and M. Chen, "Development of an Orientalstyle dairy product coagulated by microcapsules containing probiotics and filtrates from fermented rice," International Journal of Dairy Technology, vol. 60, no. 1, pp. 49-54, 2007.

[191] C. S. Fávaro-Trindade and C. R. F. Grosso, "Microencapsulation of L. acidophilus (La-05) and B. lactis (Bb-12) and evaluation of their survival at the $\mathrm{pH}$ values of the stomach and in bile," Journal of Microencapsulation, vol. 19, no. 4, pp. 485-494, 2002.

[192] C. Desmond, R. P. Ross, E. O'Callaghan, G. Fitzgerald, and C. Stanton, "Improved survival of Lactobacillus paracasei NFBC 338 in spray-dried powders containing gum acacia," Journal of Applied Microbiology, vol. 93, no. 6, pp. 1003-1011, 2002.

[193] A. Madene, M. Jacquot, J. Scher, and S. Desobry, "Flavour encapsulation and controlled release-a review," International Journal of Food Science and Technology, vol. 41, no. 1, pp. 1-21, 2006.

[194] K. Kailasapathy, "Microencapsulation of probiotic bacteria: technology and potential applications," Current Issues in Intestinal Microbiology, vol. 3, no. 2, pp. 39-48, 2002.
[195] C. Santivarangkna, U. Kulozik, and P. Foerst, "Alternative drying processes for the industrial preservation of lactic acid starter cultures," Biotechnology Progress, vol. 23, no. 2, pp. 302-315, 2007.

[196] E. Roelans and D. Taeymans, "Effect of drying condition on survival and enzyme activity of microorganisms," in Engineering and Food Volume 3, W. E. L. Spiess and H. Schubert, Eds., Advanced Process, pp. 559-569, Elsevier Applied Science, London, UK, 1990.

[197] L. J. M. Linders, W. F. Wolkers, F. A. Hoekstra, and K. van’t Riet, "Effect of added carbohydrate on membrane phase behaviour and survival of dried Lactobacillus plantarum," Cryobiology, vol. 35, no. 1, pp. 31-40, 1997.

[198] E. Selmer-Olsen, T. Sørhaug, S.-E. Birkeland, and R. Pohrson, "Survival of Lactobacillus helveticus entrapped in Ca-alginate in relation to water content, storage and rehydration," Journal of Industrial Microbiology and Biotechnology, vol. 23, no. 2, pp. 79-85, 1999.

[199] Y. Mille, J. Obert, L. Beney, and P. Gervais, "New drying process for lactic bacteria based on their dehydration behavior in liquid medium," Biotechnology and Bioengineering, vol. 88, no. 1, pp. 71-76, 2004.

[200] D. Semyonov, O. Ramon, Z. Kaplun, L. Levin-Brener, N. Gurevich, and E. Shimoni, "Microencapsulation of Lactobacillus paracasei by spray freeze drying," Food Research International, vol. 43, no. 1, pp. 193-202, 2010.

[201] A. Martinsen, G. Skjak-Braek, and O. Smidsrod, "Alginate as immobilization material: i. Correlation between chemical and physical properties of alginate gel beads," Biotechnology and Bioengineering, vol. 33, no. 1, pp. 79-89, 1989.

[202] J. Klein, J. Stock, and K.-D. Vorlop, "Pore size and properties of spherical Ca-alginate biocatalysts," European Journal of Applied Microbiology and Biotechnology, vol. 18, no. 2, pp. 86-91, 1983.

[203] H. Eikmeier and H. J. Rehm, "Stability of calcium-alginate during citric acid production of immobilized Aspergillus niger," Applied Microbiology and Biotechnology, vol. 26, no. 2, pp. 105111, 1987.

[204] J. C. Ellenton, Encapsulation bifidobacteria [M.S. thesis], University of Guelph, Guelph, Canada, 1998.

[205] M. T. Cook, G. Tzortzis, D. Charalampopoulos, and V. V. Khutoryanskiy, "Microencapsulation of probiotics for gastrointestinal delivery," Journal of Controlled Release, vol. 162, pp. 56-57, 2012.

[206] C. P. Champagene and P. Fustier, "Microencapsulation for delivery of probiotics and other ingredients in functional dairy products," Functional Dairy Products, vol. 2, pp. 404-426, 2007.

[207] G. K. Gbassi and T. Vandamme, "Probiotic encapsulation technology: from microencapsulation to release into the gut," Pharmaceutics, vol. 4, no. 1, pp. 149-163, 2012.

[208] A. H. King, "Encapsulation of food ingredients: a review of available technology, focussing on hydrocolloid," in Encapsulation and Controlled Release of Food Ingredients, J. R. Sara and A. R. Gary, Eds., vol. 590 of ACS Symposium Series, pp. 26-39, American Chemical Society, Washington, DC, USA.

[209] K. Kailasapathy, "Encapsulation technologies for functional foods and nutraceutical product development," CAB Reviews, vol. 4, no. 6, pp. 1-19, 2009.

[210] P. de Vos, M. M. Faas, M. Spasojevic, and J. Sikkema, "Encapsulation for preservation of functionality and targeted delivery of bioactive food components," International Dairy Journal, vol. 20, no. 4, pp. 292-302, 2010. 
[211] O. Smidsrod and G. Skjak-Braek, "Alginate as immobilization matrix for cells," Trends in Biotechnology, vol. 8, no. 3, pp. 71-75, 1990.

[212] S. Overgaard, J. M. Scharer, M. Moo-Young, and N. C. Bols, "Immobilization of hybridoma cells in chitosan alginate beads," Canadian Journal of Chemical Engineering, vol. 69, no. 2, pp. 439-443, 1991.

[213] C. Lacroix, C. Paquin, and J.-P. Arnaud, "Batch fermentation with entrapped growing cells of Lactobacillus casei. Optimization of the rheological properties of the entrapment gel matrix," Applied Microbiology and Biotechnology, vol. 32, no. 4, pp. 403408, 1990.

[214] A. W. Adamson, Physical Chemistry of Surfaces, Wiley, New York, NY, USA, 1982.

[215] T. Heidebach, P. Först, and U. Kulozik, "Microencapsulation of probiotic cells by means of rennet-gelation of milk proteins," Food Hydrocolloids, vol. 23, no. 7, pp. 1670-1677, 2009.

[216] T. Heidebach, P. Först, and U. Kulozik, "Transglutaminaseinduced caseinate gelation for the microencapsulation of probiotic cells," International Dairy Journal, vol. 19, no. 2, pp. 77-84, 2009.

[217] Y. D. Livney, "Milk proteins as vehicles for bioactives," Current Opinion in Colloid and Interface Science, vol. 15, no. 1-2, pp. 7383, 2010.

[218] J. Yáñez-Fernández, E. G. Ramos-Ramírez, and J. A. SalazarMontoya, "Rheological characterization of dispersions and emulsions used in the preparation of microcapsules obtained by interfacial polymerization containing Lactobacillus sp," European Food Research and Technology, vol. 226, no. 5, pp. 957-966, 2008.

[219] A. Dimantov, M. Greenberg, E. Kesselman, and E. Shimoni, "Study of high amylose corn starch as food grade enteric coating in a microcapsule model system," Innovative Food Science and Emerging Technologies, vol. 5, no. 1, pp. 93-100, 2003.

[220] M. J. Pikal, "Freeze-drying of protein, part-I: process design," PharmTech International, vol. 1, pp. 37-43, 1991.

[221] A. R. Donthidi, R. F. Tester, and K. E. Aidoo, "Effect of lecithin and starch on alginate-encapsulated probiotic bacteria," Journal of Microencapsulation, vol. 27, no. 1, pp. 67-77, 2010.

[222] N. Huyghebaert, A. Vermeire, P. Rottiers, E. Remaut, and J. P. Remon, "Development of an enteric-coated, layered multiparticulate formulation for ileal delivery of viable recombinant Lactococcus lactis," European Journal of Pharmaceutics and Biopharmaceutics, vol. 61, no. 3, pp. 134-141, 2005.

[223] H. Hayashi, E. Kumazawa, Y. Saeki, and Y. Ishioka, "Continuous vaccum dryer for energy saving," Drying Technology, vol. 1, no. 2, pp. 275-284, 1983.

[224] Z. L. Wang, W. H. Finlay, M. S. Peppler, and L. G. Sweeney, "Powder formation by atmospheric spray-freeze-drying," Powder Technology, vol. 170, no. 1, pp. 45-52, 2006.

[225] H. Durand and J. Panes, "Particles containing coated living micro-organisms, and method for producing same," US patent and Trademark Office, N20030109025.

[226] V. Truong, D. A. Clare, G. L. Catignani, and H. E. Swaisgood, "Cross-linking and rheological changes of whey protein treated with microbial transglutaminase," Journal of Agricultural and Food Chemistry, vol. 52, no. 5, pp. 1170-1176, 2004.

[227] B. R. Bhandari, N. Datta, B. R. D’Arcy, and G. B. Rintoul, "Co-crystallization of honey with sucrose," Food Science and Technology, vol. 31, no. 2, pp. 138-142, 1998.
[228] A. Hedges and C. McBride, "Utilization of $\beta$-cyclodextrin in food," Cereal Foods World, vol. 44, no. 10, pp. 700-704, 1999.

[229] F. T. Gentile, E. J. Doherty, D. H. Rein, M. S. Shoichet, and S. R. Winn, "Polymer science for macroencapsulation of cells for central nervous system transplantation," Reactive Polymers, vol. 25, no. 2-3, pp. 207-227, 1995.

[230] Z. Dong, Q. Wang, and Y. Du, "Alginate/gelatin blend films and their properties for drug controlled release," Journal of Membrane Science, vol. 280, no. 1-2, pp. 37-44, 2006.

[231] K. I. Draget, K. Steinsvåg, E. Onsøyen, and O. Smidsrød, " $\mathrm{Na}^{+}$and $\mathrm{K}^{+}$alginate; effect on $\mathrm{Ca}^{2+}$-gelation," Carbohydrate Polymers, vol. 35, no. 1-2, pp. 1-6, 1998.

[232] T. Harnsilawat, R. Pongsawatmanit, and D. J. McClements, "Characterization of $\beta$-lactoglobulin-sodium alginate interactions in aqueous solutions: a calorimetry, light scattering, electrophoretic mobility and solubility study," Food Hydrocolloids, vol. 20, no. 5, pp. 577-585, 2006.

[233] L. T. Hansen, P. M. Allan-Wojtas, Y.-L. Jin, and A. T. Paulson, "Survival of Ca-alginate microencapsulated Bifidobacterium spp. in milk and simulated gastrointestinal conditions," Food Microbiology, vol. 19, no. 1, pp. 35-45, 2002.

[234] G. F. Fanta, C. A. Knutson, K. S. Eskins, and F. C. Felker, "Starch microcapsules for delivery of active agents," US patent. 2001, 6, 238, 677 .

[235] S. G. Haralampu, "Resistant starch-a review of the physical properties and biological impact of RS3," Carbohydrate Polymers, vol. 41, no. 3, pp. 285-292, 2000.

[236] C. J. Malm, J. Emerson, and G. D. Hiatt, "Cellulose acetate phthalate as an enteric coating material," Journal of the American Pharmaceutical Association, vol. 40, no. 10, pp. 520-525, 1951.

[237] S. Gaaloul, S. L. Turgeon, and M. Corredig, "Influence of shearing on the physical characteristics and rheological behaviour of an aqueous whey protein isolate-kappa-carrageenan mixture," Food Hydrocolloids, vol. 23, no. 5, pp. 1243-1252, 2009.

[238] Y. Yuguchi, T. T. T. Thuy, H. Urakawa, and K. Kajiwara, "Structural characteristics of carrageenan gels: temperature and concentration dependence," Food Hydrocolloids, vol. 16, no. 6, pp. 515-522, 2002.

[239] M. R. Mangione, D. Giacomazza, D. Bulone, V. Martorana, and P. L. san Biagio, "Thermoreversible gelation of $\kappa$-Carrageenan: relation between conformational transition and aggregation," Biophysical Chemistry, vol. 104, no. 1, pp. 95-105, 2003.

[240] H. P. Sarett, "Safety of carrageenan used in foods," The Lancet, vol. 1, no. 8212, pp. 151-152, 1981.

[241] Y. Doleyres, I. Fliss, and C. Lacroix, "Continuous production of mixed lactic starters containing probiotic using immobilised cell technology," Biotechnology Progress, vol. 20, no. 1, pp. 145150, 2004.

[242] J. Klien and D. K. Vorlop, "Immobilisation technique cells," in Comprehensive Biotechnology, M. Moo-Yong, C. L. Cooney, and A. E. Humphery, Eds., pp. 542-550, Pergamon Press, Oxford, UK, 1985.

[243] S. Rokka and P. Rantamäki, "Protecting probiotic bacteria by microencapsulation: challenges for industrial applications," European Food Research and Technology, vol. 231, no. 1, pp. 1-12, 2010.

[244] A. A. Reid, C. P. Champagne, N. Gardner, P. Fustier, and J. C. Vuillemard, "Survival in food systems of Lactobacillus rhamnosus R011 microentrapped in whey protein gel particles," Journal of Food Science, vol. 72, no. 1, pp. M31-M37, 2006. 

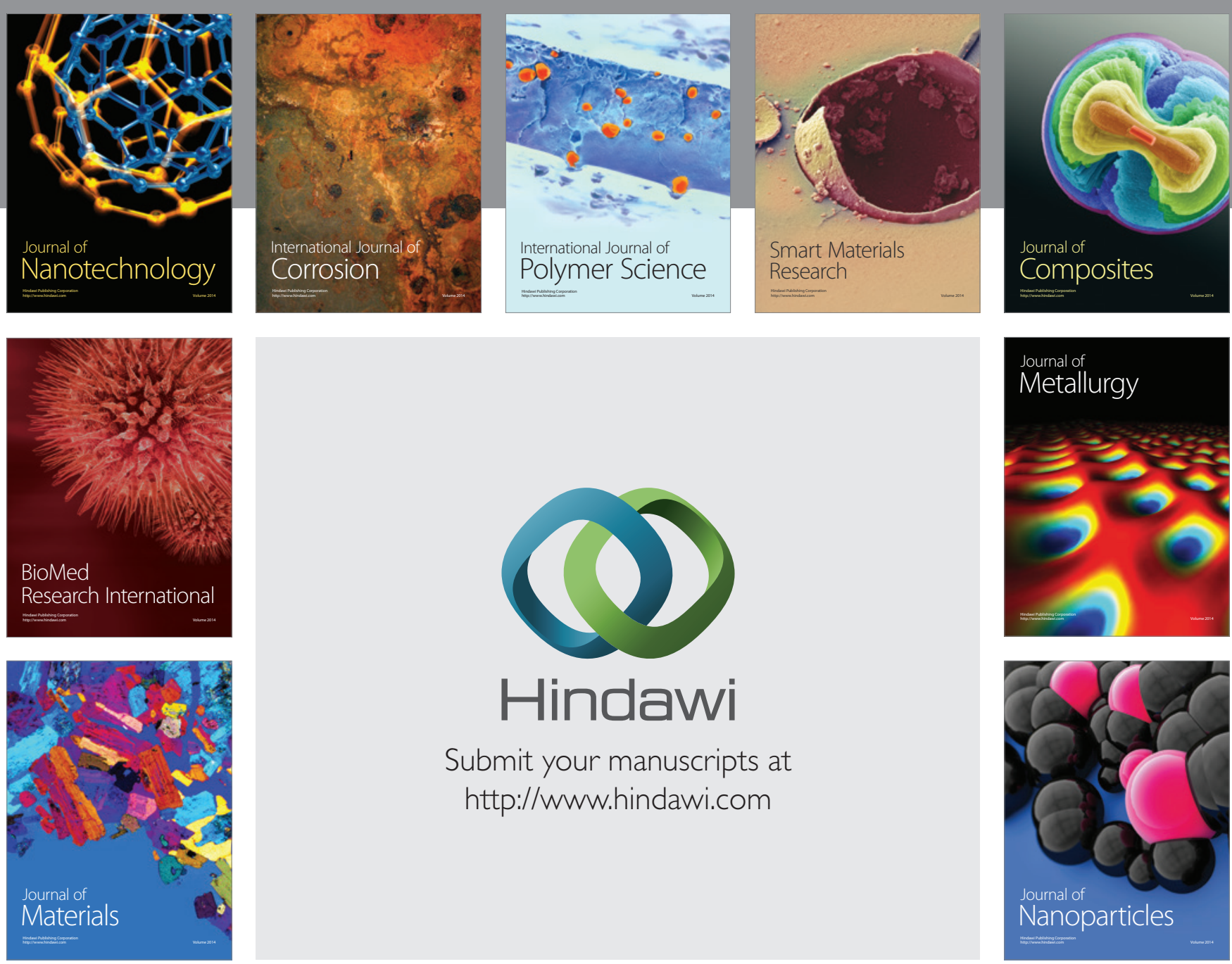

Submit your manuscripts at http://www.hindawi.com
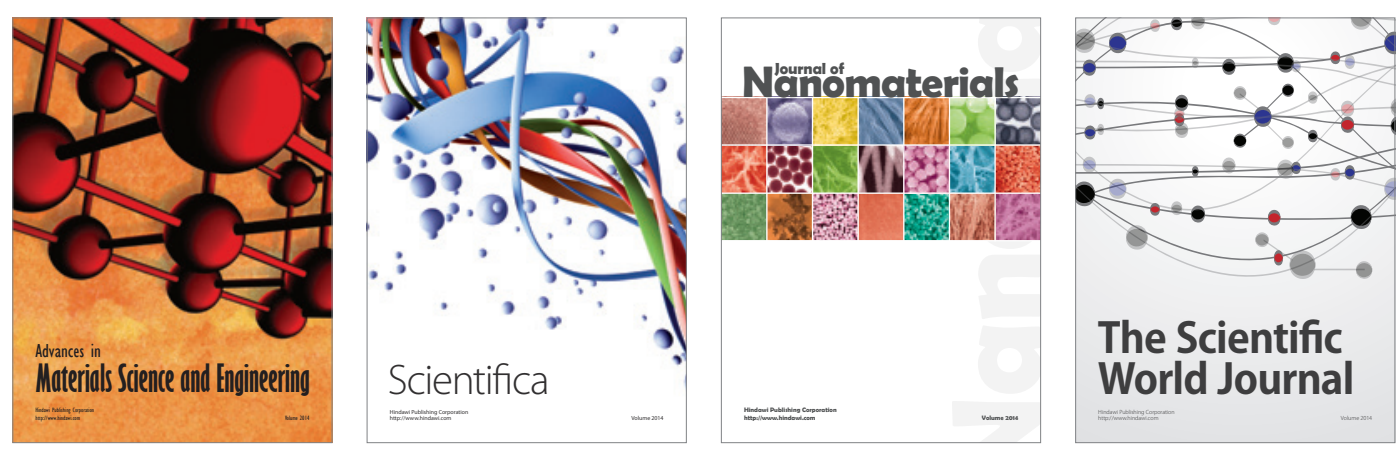

\section{The Scientific World Journal}
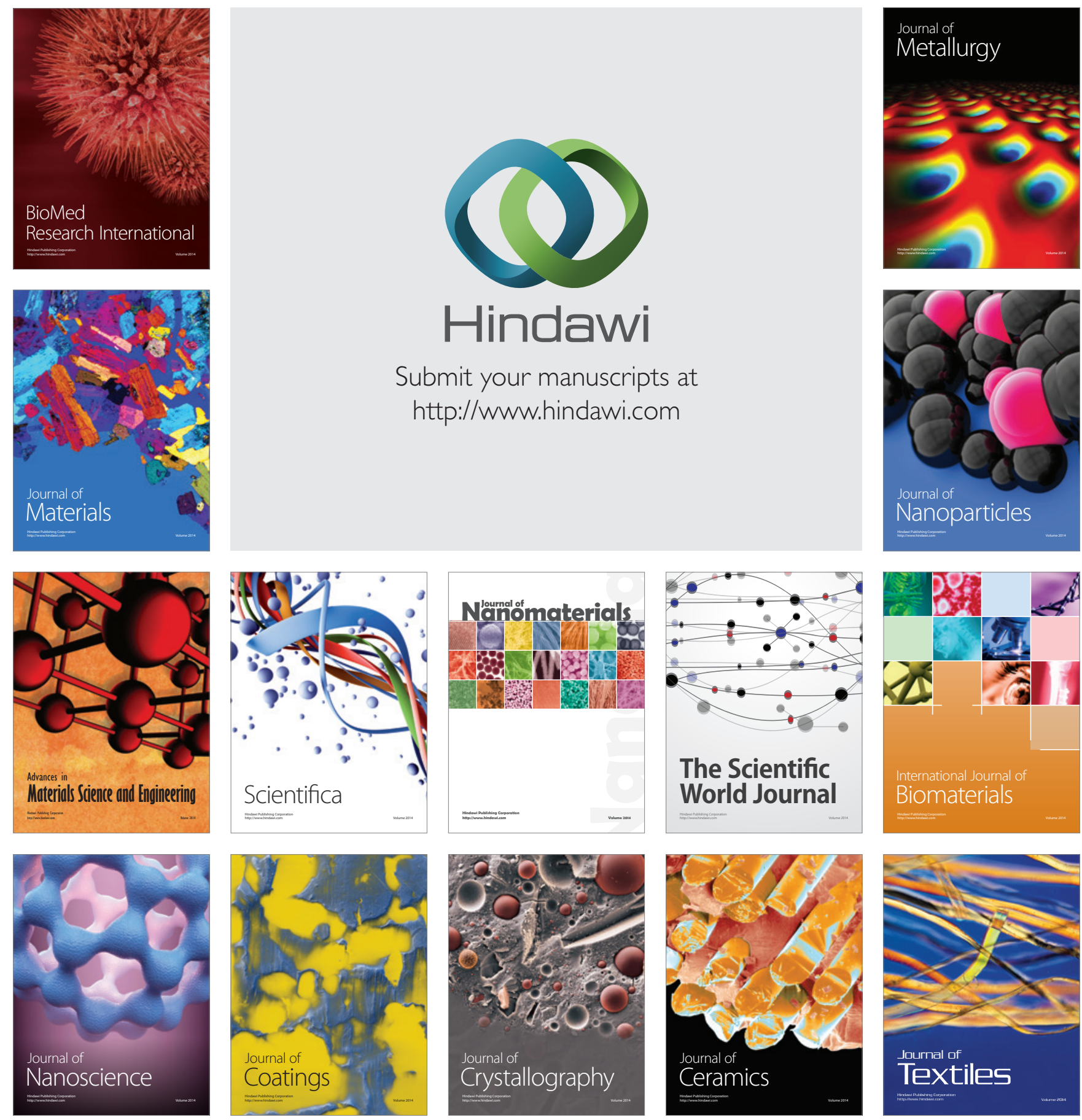